\title{
Multi criteria Decision Analysis Algorithm based Optimal Selection of PV Panel for Grid-tie PV Electricity Generation System in context of Dhaka, Bangladesh
}

\author{
Md. Abubokar Talukdar ${ }^{1}$, Hamidur Rahman², Pejush Chandra Sarker ${ }^{3}$ \\ Research Scholar, Department of EEE, Bangladesh University of Engineering and Technology, Dhaka, Bangladesh ${ }^{1}$ \\ Associate Professor, Department of EEE, Bangladesh University of Engineering and Technology, Dhaka, Bangladesh ${ }^{2}$ \\ Lecturer, Department of EEE, Rajshahi University of Engineering and Technology, Rajshahi, Bangladesh ${ }^{3}$
}

\begin{abstract}
Solar electricity from photovoltaic (PV) panel is the important source of renewable energy and it is being popular all over the world due to enhancement of solar PV technology. There are sorts of PV panels having individually different solar performance features manufactured by different manufactures in different countries. Per watt cost, efficiency, life time etc are different for different types of PV panels. Due to difference in efficiencies, different panels require different amount of land usage for generation of same amount of electricity. Per unit electricity $(\mathrm{kWh})$ generation cost is also different for different types of panels. It is an important concern to reduce land usage and per unit electricity cost. This paper deals with optimal selection of PV panel for grid tie PV power plant using multicriteria decision analysis (MCDA) algorithm. The Technique for Order of Preference by Similarity to Ideal Solution (TOPSIS) is adopted as MCDA tool for optimal selection of PV panel considering land usage and per kWh generation cost criteria. Several investigations are performed for different weighing of the criteria. This study could be assumed as a powerful road map for decision makers, analysts and policy makers in context of Bangladesh.
\end{abstract}

Keywords: Optimal selection, Grid tie power plant, solar PV electricity, Multi-criteria decision analysis (MCDA), Technique for Order of Preference by Similarity to Ideal Solution (TOPSIS).

\section{NOMENCLATURE}

$\varnothing$
Long
GMT
$A_{\text {zsun }}$
$\Theta_{A}$
$\rho$
GHI $(t)$
DIF (t)
DHI (t)
$\beta_{\text {tilt }}$
$A_{\text {zpanel }}$
G (t)
$V_{\text {OCSTC }}$
$V_{\text {OC }}(t)$
$I_{\text {SCSTC }}$
$I_{\text {SC }}(t)$

Latitude

Longitude

Greenwich Mean Time

Azimuth angle of the sun

Altitude angle of the sun

Ground albedo

Global Horizontal Irradiance

Diffuse Horizontal

Irradiance

Direct Horizontal Irradiance

Solar panel tilt angle

Solar panel azimuth angle

Solar irradiance on tilted

surface

Open circuit voltage under

standard test condition

Open circuit voltage under

operating condition

Short circuit current under standard test condition

Short circuit current under operating condition

NOCT
$\mathrm{T}_{\mathrm{A}}$
$\mathrm{T}_{\text {ref }}$
$\mathrm{T}_{\mathrm{C}}(\mathrm{t})$
$\mathrm{K}_{\mathrm{v}}$
$\mathrm{K}_{\mathrm{i}}$
$\mathrm{E}_{\text {reqday }}$
$\mathrm{Mg}$
$\mathrm{\eta}_{\text {inv }}$
FF
$\mathrm{f}_{\text {exploit }}$
Area
$\mathrm{N}_{\text {lifepv }}$
$\mathrm{N}_{\text {lifeinv }}$
$\mathrm{N}_{\text {lifesupport }}$

Nominal operating cell temperature

Ambient temperature

PV panel reference

temperature, $25^{\circ} \mathrm{C}$

Operating PV temperature

Open circuit voltage co-

efficient

Short circuit current co-

efficient

Daily electricity production

target

Gradient for the linearly derated efficiency curve

Inverter efficiency

Fill factor

Area exploitation factor

Grid substation area

Life time of PV panel

Life time of PV inverter

Life time of PV panel 
International Journal of Innovative Research in

\section{Electrical, Electronics, Instrumentation and Control Engineering}

ISO 3297:2007 Certified

Vol. 5, Issue 2, February 2017

\begin{tabular}{|c|c|}
\hline $\mathrm{N}_{\text {lifesubstation }}$ & Life time of grid substation \\
\hline $\mathrm{N}_{\text {lifeland }}$ & Life time of land \\
\hline $\mathrm{N}_{\text {lifeproject }}$ & Life time of project \\
\hline Price $_{\text {purpv }}$ & $\begin{array}{l}\text { Purchasing price of PV } \\
\text { panels per watt }\end{array}$ \\
\hline Price $_{\text {purinv }}$ & $\begin{array}{l}\text { Purchasing price of } \mathrm{PV} \\
\text { inverter per watt }\end{array}$ \\
\hline Price $_{\text {supportpv }}$ & $\begin{array}{l}\text { Price for support of PV } \\
\text { panels per } \mathrm{m}^{2}\end{array}$ \\
\hline Price $_{\text {substation }}$ & $\begin{array}{l}\text { Construction price of grid } \\
\text { substation per watt }\end{array}$ \\
\hline Price $_{\text {purland }}$ & $\begin{array}{l}\text { Purchasing price of land per } \\
\text { acres }\end{array}$ \\
\hline Price $_{\text {landdev }}$ & $\begin{array}{l}\text { Cost of land development } \\
\text { per acres }\end{array}$ \\
\hline$\%$ Salvage $\mathrm{pv}$ & $\begin{array}{l}\text { Percentage of salvage value } \\
\text { of PV panels, of its initial } \\
\text { investment }\end{array}$ \\
\hline$\%$ Salvage inverter & $\begin{array}{l}\text { Percentage of salvage value } \\
\text { of PV inverter, of its initial } \\
\text { investment }\end{array}$ \\
\hline$\%$ Salvage support $_{\text {}}$ & $\begin{array}{l}\text { Percentage of salvage value } \\
\text { of PV panel supports, of its } \\
\text { initial investment }\end{array}$ \\
\hline$\%$ Salvage substation & $\begin{array}{l}\text { Percentage of salvage value } \\
\text { of grid substation, of its } \\
\text { initial investment }\end{array}$ \\
\hline$\%$ Salvage ${ }_{\text {land }}$ & $\begin{array}{l}\text { Percentage of salvage value } \\
\text { of land, of its initial } \\
\text { investment }\end{array}$ \\
\hline$\beta$ & Inflation rate \\
\hline$\gamma$ & Interest rate \\
\hline$\Psi$ & Escalation rate \\
\hline$N_{\text {techstaff }}$ & No. of technical staffs \\
\hline$N_{\text {secustaff }}$ & No. of security staffs \\
\hline Salary $_{\text {techstaff }}$ & Salary of each technical staff \\
\hline Salary $_{\text {secustaff }}$ & Salary of each security guard \\
\hline Price $_{\text {ompv }}$ & $\begin{array}{l}\text { Yearly maintenance cost of } \\
\text { PV panel per watt }\end{array}$ \\
\hline Price $_{\text {omsupport }}$ & $\begin{array}{l}\text { Yearly maintenance cost of } \\
\text { PV panel support per } m^{2}\end{array}$ \\
\hline Price $_{\text {ominv }}$ & $\begin{array}{l}\text { Yearly maintenance cost of } \\
\text { PV inverter per watt }\end{array}$ \\
\hline Price $_{\text {omsubstation }}$ & $\begin{array}{l}\text { Yearly maintenance cost of } \\
\text { grid substation per watt. }\end{array}$ \\
\hline Price $_{\text {omland }}$ & $\begin{array}{l}\text { Yearly maintenance cost of } \\
\text { land per acre. }\end{array}$ \\
\hline
\end{tabular}

\section{INTRODUCTION}

The production of electricity in 2013 was 23,321 TWh. Sources of electricity were fossil fuels $67 \%$, renewable energy $16 \%$ (mainly hydroelectric, wind, solar and biomass), and nuclear power $13 \%$, and other sources were
$4 \%$. The majority of fossil fuel usage for the generation of electricity was coal and gas[1]. Due to depletion of fossil fuels and serious pollution occurring from usage of fossil fuels as source of energy, renewable energy sources are becoming popular for generation of electricity. Among the many other renewable energy sources solar photovoltaic (PV) electricity is more feasible due to direct conversion of electricity from solar irradiance and it requires less maintenance in comparison with other renewable electricity sources. There are several PV technologies for extraction of electricity using PV panels. Selection of PV panel is very important for optimization of PV plant design considering specified criteria.

\section{PROBLEM STATEMENT}

Wattpeak $\left(W_{p}\right)$ rating of $\mathrm{PV}$ panel is the maximum amount of power converted by $\mathrm{PV}$ panel under standard test conditions (STC). Under standard test condition, solar irradiance level is $1000 \mathrm{~W} / \mathrm{m}^{2}$, panel temperature is $25^{\circ} \mathrm{C}$ and air mass (AM) is 1.5 [2]. Power conversion from panel varies for different times of a day as solar irradiance changes. Even in solar day peak time power produced from the panel is less than $W_{p}$ as solar irradiance level is less than $1000 \mathrm{~W} / \mathrm{m}^{2}$. There are several manufacturing companies in the world which manufacture solar panels having different solar performance. Efficiency, per watt price, lifetime, and degradation of wattpeak rating over life span are widely varied with manufacturers and PV technologies. Doubly efficient panel requires half area to produce same amount of power. Highly efficient PV panel reduces the land requirement, but per watt price of high efficient panel is higher and hence per $\mathrm{kWh}$ electricity generation cost may be higher. Panel should be so chosen that reduces both per $\mathrm{kWh}$ generation electricity cost and land usage.

\section{III.PROBLEM SOLVING APPROACH}

In this paper daily electricity production capacity and location of PV plant are preliminarily determined. Few PV panels are preliminarily selected and several alternatives are formed for individual PV panel. For grid tie PV electricity system, per kWh electricity production cost and required area for PV plant are calculated for each alternative using input location data (i.e.; latitude, longitude, solar azimuth angle, sun altitude angle etc.), solar data (i.e.; temperature, diurnal solar irradiance etc), PV panel data (open circuit voltage and short circuit current under standard test condition, temperature coefficient of open circuit voltage and short circuit current, NOCT, efficiency, physical dimension, FF, weight etc.), design data (tilt angle, azimuth orientation of panel, area exploitation factor, inter row spacing etc.).

Per kWh cost and required area for PV plant are the two criteria which are preliminarily preferred by weighing method. Now ranking of all alternatives is made using 
Vol. 5, Issue 2, February 2017

TOPSIS multicriteria decision analysis algorithm. Panel corresponding to the best alternative is the optimal selected PV panel.

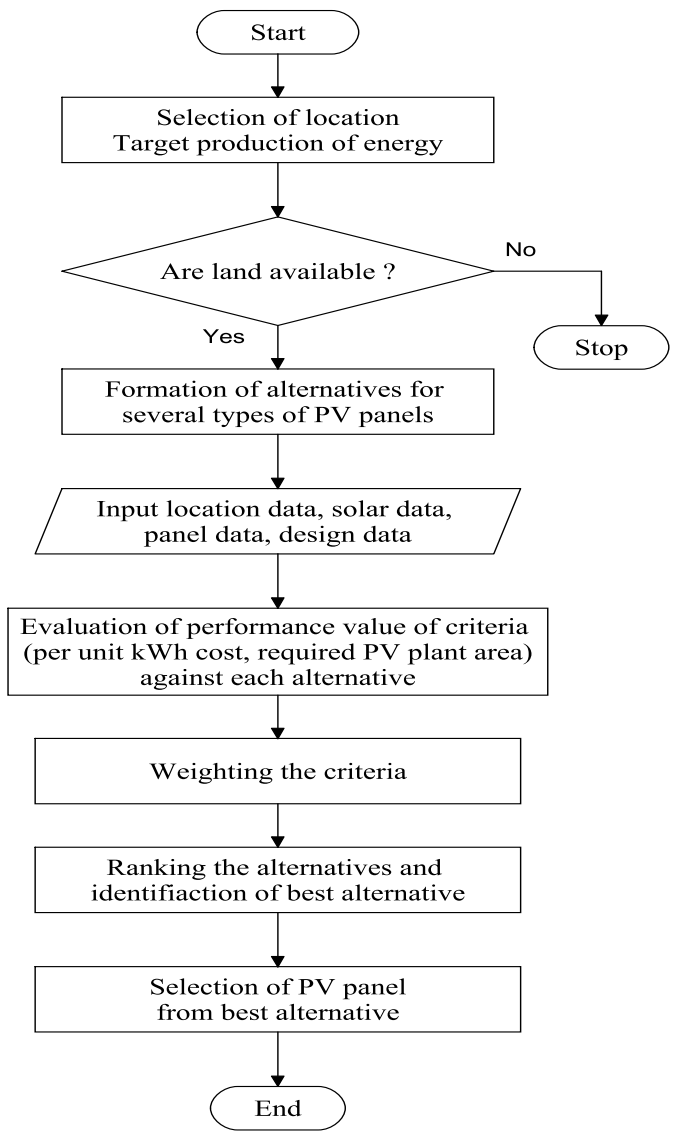

Fig.1: Flow chart for selection of PV panel.

\section{IV.DETERMINATION OF SOLAR IRRADIANCE ON TILTED PV PANEL}

Available solar data GHI and DIF are irradiance on horizontal surfaces. But PV panels are titled and panel azimuth oriented to receive maximum irradiance. In this paper, yearly fixed PV panels are considered. Solar irradiance on tilted PV panel is calculated using equations as follows. Direct beam on tilted surface [3]-[4],

$\{0$,

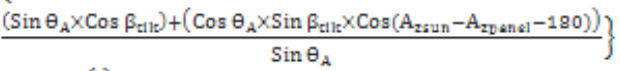

$$
\begin{aligned}
& \times(\mathrm{GHI}(\mathrm{t})-\mathrm{DIF}(\mathrm{t}))
\end{aligned}
$$

Pseudo-isotropic model proposed by authors in [5] diffuse beam on tilted surface,

$$
D I F_{\text {tilt }}(t)=\left(\frac{3+\operatorname{Cos}\left(2 \beta_{\text {tilt }}\right)}{4}\right) \times D I F(t)
$$

Using equation as in [6] ground reflected beam on tilted surface,

\section{$R E F_{\text {tilt }}(t)=\rho\left(\frac{1-\operatorname{Cos} \beta_{\text {tilt }}}{2}\right) \times G H I(t)$ \\ Solar irradiance on tilted surface, \\ $G(t)=D H I_{\text {tilt }}(t)+D I F_{\text {tilt }}(t)+R E F_{\text {tilt }}(t) \quad \ldots \ldots 4$ \\ V. A PV SYSTEM MODEL AND CALCULATION OF PV PLANT AREA}

Power produced by the PV panel can be calculated using following equations [7].

Open circuit voltage:

$$
V_{O C}(t)=V_{\text {OCSTC }}+K_{v}\left(T_{C}(\mathrm{t})-T_{\text {ref }}\right) \quad \ldots \ldots .5
$$

Short circuit current:

$$
I_{S C}(t)=\left[I_{S C S T C}+K_{i}\left(T_{C}(t)-T_{\text {ref }}\right)\right] \times \frac{G(t)}{1000} \quad \ldots \ldots 6
$$

Where

$$
T_{C}(\mathrm{t})=T_{A}+\frac{N O C T-200}{800} \times G(t)
$$

Instantaneous power produced from a panel,

$$
P_{\text {Pan elnew }}(\mathrm{t})=\eta_{\text {inv }} \times \mathrm{FF} \times V_{O C}(t) \times I_{S C}(t)
$$

A. Annual average electricity production by a PV panel

Annual average electricity production by a PV panel can be calculated using following relationships.

Daily electricity production by a new panel,

$$
\begin{aligned}
& E_{\text {Pdnew }}=\sum_{t=1}^{24} P_{\text {Panel }}(t) \\
& =\eta_{\text {inv }} \times \mathrm{FF} \times \sum_{t=1}^{24} V_{O C}(t) \times I_{S C}(t)
\end{aligned}
$$

Annual electricity production by a new panel,

$$
E_{\text {Pynew }}=\sum_{t=1}^{365} E_{\text {Pdnew }}(t)
$$

PV panel life time average of annual electricity production by a panel,

$$
E_{\text {Pyavg }}=\frac{E_{\text {Pynew }} \quad \sum_{t=0}^{N_{\text {life }}-1} \frac{(100-M g \times t)}{100}}{N_{\text {life }}}
$$

B. Area for PV plant

Annual target of electricity,

$$
E_{\text {reqyear }}=365 \times E_{\text {reqday }}
$$

Number of panels required,

$$
N_{p v}=\frac{E_{\text {reqyear }}}{E_{\text {Pyavg }}}
$$

Watt-peak rating of PV plant,

$$
\text { Wpeak }_{P V}=\text { Wattpeak }_{\text {Panel }} \times N_{P V}
$$

Solar radiation sensitive panel area,

Area $_{\text {Panel }}=$ Length $_{\text {Panel }} \times W i d t h_{\text {Panel }}$

PV panel installation area in acre, 
Vol. 5, Issue 2, February 2017

$$
\begin{aligned}
& \text { Area }_{P V}=\frac{N_{P V} \times \text { Area }_{\text {Panel }}}{f_{\text {exploit }}} \times \frac{1}{4046.8} \\
& \text { Total PV plant area, }
\end{aligned}
$$

$$
\text { Area }_{\text {Plant }}=\text { Area }_{P V}+\text { Area }_{\text {grid }}
$$

\section{COST ESTIMATION FOR GRID TIE PV PLANT}

A. Initial investment

Initial investment for purchasing PV panels,

$$
\text { Invest }_{\text {purpv }}=\text { Price }_{\text {purpv }} \times \text { Wattpeak } k_{P V}
$$

Wattage rating of both inverter and substation is $90 \%$ of Wattpeak rating of PV plant as solar irradiation does not reach $900 \mathrm{~W} / \mathrm{m}^{2}$ even in the sunny day peak for the site location (Dhaka, Bangladesh).

$$
\begin{aligned}
& \text { Watt }_{\text {inv }}=\quad \text { Watt }_{\text {substation }} \\
& 0.90 \times \text { Wattpeak }
\end{aligned}
$$

Initial investment for purchasing PV inverter,

$$
\text { Invest }_{\text {inverter }}=\text { Price }_{\text {purinv }} \times \text { Watt }_{\text {inv }}
$$

Initial investment for construction of panel supports,

$$
\text { Invest }_{\text {support }}=\text { Price }_{\text {supportpv }} \times \text { Area }_{\text {pv }}
$$

Initial investment for grid substation,

$$
\begin{aligned}
& \text { Invest }_{\text {substation }} \\
& \times \text { Watt }_{\text {substation }}
\end{aligned} \quad \text { Price }_{\text {substation }} \ldots \ldots 22
$$

Initial investment for purchasing land,

Invest $_{\text {land }}=$ Price $_{\text {purland }} \times$ Area $_{\text {plant }}$

Initial investment for land development,

$$
\text { Invest }_{\text {landdev }}=\text { Price }_{\text {landdev }} \times \text { Are }_{\text {plant }}
$$

B. Present worth of salvage value

Present worth of salvage value is calculated as in [8] using following equations.

Present worth of salvage value of PV panels,

$\mathrm{PSV}_{\text {panel }}=\%$ Salvage $_{\mathrm{pv}} \times$ Invest $_{\text {purpv }} \times\left(\frac{1+\beta}{1+\gamma}\right)^{\mathrm{N}_{\text {lifepv }}} \ldots .25$

Present worth of salvage value of PV inverter,

PSV $_{\text {inverter }}=\%$ Salvage $_{\text {inv }} \times$ Invest $_{\text {purinv }} \times\left(\frac{1+\beta}{1+\gamma}\right)^{\mathrm{N}_{\text {lifeinv }}} \ldots 26$

Present worth of salvage value of panel supports,

PSV $_{\text {support }}=\%$ Salvage $_{\text {suppprt }} \times$ Invest $_{\text {support }}$ $\times\left(\frac{1+\beta}{1+\gamma}\right)^{\mathrm{N}_{\text {lifesupport }}}$

Present worth of salvage value of grid substation,

$$
\begin{gathered}
\text { PSV }_{\text {substation }}=\% \text { Salvage }_{\text {support }} \\
\text { Invest }_{\text {support }} \times\left(\frac{1+\beta}{1+\gamma}\right)^{\mathrm{N}_{\text {lifesubstation }}} \quad \ldots 28
\end{gathered}
$$

Present worth of salvage value of land,

$\mathrm{PSV}_{\text {land }}=\%$ Salvage $_{\text {land }} \times$ Invest $_{\text {land }} \times\left(\frac{1+\beta}{1+\gamma}\right)^{\mathrm{N}_{\text {lifeland }}}$
C. Present worth of maintenance cost

Present worth of maintenance cost is calculated as in [8] using following equations.

Present worth of maintenance cost of PV panels,

$$
\mathrm{OM}_{\mathrm{pv}}=\text { Price }_{\mathrm{ompv}} \times \text { Wattpeak }_{\mathrm{pv}} \sum_{\mathrm{i}=1}^{\mathrm{N}_{\text {lifepv }}}\left(\frac{1+\psi}{1+\gamma}\right)^{\mathrm{i}} \ldots . .30
$$

Present worth of maintenance cost of PV inverter,

$$
\mathrm{OM}_{\text {inverter }}=\text { Price }_{\text {ominv }} \times \text { Watt }_{\text {inv }} \sum_{\mathrm{i}=1}^{\mathrm{N}_{\text {lifeinv }}}\left(\frac{1+\psi}{1+\gamma}\right)^{\mathrm{i}} \ldots 31
$$

Present worth of maintenance cost of PV panels supports,

$$
\begin{gathered}
\text { OM }_{\text {support }}= \\
\text { Price }_{\text {omsuppv }} \times \text { Area }_{\text {pv }} \sum_{\mathrm{i}=1}^{\mathrm{N}_{\text {lifesupport }}} \\
\left(\frac{1+\psi}{1+\gamma}\right)^{\mathrm{i}} \ldots .32
\end{gathered}
$$

Present worth of maintenance cost of grid substation, $\mathrm{OM}_{\text {substation }}=$

Price $_{\text {omsubs }} \times$ Watt $_{\text {substation }} \sum_{\mathrm{i}=1}^{\mathrm{N}_{\text {lifesubstation }}} \quad\left(\frac{1+\psi}{1+\gamma}\right)^{\mathrm{i}} \ldots \ldots 33$

Present worth of maintenance cost of land development,

$\mathrm{OM}_{\text {landdev }}=$ Price $_{\text {omland }} \times$ Area $_{\text {plant }} \cdot \sum_{\mathrm{i}=1}^{\mathrm{N}_{\text {lifeland }}}\left(\frac{1+\psi}{1+\gamma}\right)^{\mathrm{i}} \quad \ldots 34$

Present worth of operating cost (Salary of staffs),

$$
\begin{gathered}
\mathrm{OM}_{\text {salary }}=\left(\text { Salary } \text { techstaff } \times \mathrm{N}_{\text {techstaff }}+\text { Salary }_{\text {secustaff }} \times\right. \\
\left.\mathrm{N}_{\text {secustaff }}\right) \times 14.2 \times \sum_{\mathrm{i}=1}^{\mathrm{N}_{\text {lifeproject }}}\left(\frac{1+\psi}{1+\gamma}\right)^{\mathrm{i}} \quad \ldots .35
\end{gathered}
$$

D. Total annual cost

Annual cost of PV plant is calculated using following equations [5].

Annual cost for solar panels,

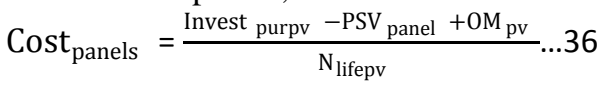

Annual cost for panel supports,

$$
\text { Cost }_{\text {support }}=\frac{\text { Invest } \text { support }-\mathrm{PSV}_{\text {support }}+\mathrm{OM}_{\text {support }}}{\mathrm{N}_{\text {lifesupport }}} \ldots .37
$$

Annual cost for PV inverter,

$$
\text { Cost }_{\text {inverter }}=\frac{\text { Invest }_{\text {inverter }}-\mathrm{PSV}_{\text {inverter }}+\mathrm{OM}_{\text {inverter }}}{\mathrm{N}_{\text {lifeinverter }}} \ldots 38
$$

Annual cost for grid substation,

Cost $_{\text {substation }}=\frac{\text { Invest } \text { substation }-\mathrm{PSV}_{\text {substation }}+\mathrm{OM}_{\text {substation }}}{\mathrm{N}_{\text {lifesubstation }}} .39$

Annual cost for land,

$$
\text { Cost }_{\text {land }}=\frac{\text { Invest }_{\text {land }}+\text { Invest }_{\text {landdev }}-\mathrm{PSV}_{\text {land }}+\mathrm{OM}_{\text {land }}}{\mathrm{N}_{\text {lifeland }}} \ldots 40
$$

Annual cost for salary of staff,

$$
\text { Cost }_{\text {salary }}=\frac{\mathrm{OM}_{\text {salary }}}{\mathrm{N}_{\text {lifeproject }}} \quad \ldots .41
$$

Total Annual cost,

$$
\begin{gathered}
\text { Cost }_{\text {year }}=\text { Cost }_{\text {panels }}+\text { Cost }_{\text {support }}+\text { Cost }_{\text {inverter }}+ \\
\text { Cost }_{\text {substation }}+\text { Cost }_{\text {land }}+\text { Cost }_{\text {salary }} \quad \ldots 42
\end{gathered}
$$


Vol. 5, Issue 2, February 2017

E. Per unit electricity $(\mathrm{kWh})$ generation cost Per unit electricity $(\mathrm{kWh})$ generation cost in BDT,

$$
k W h_{\text {cost }}=\frac{\text { Cost }_{\text {year }}}{E_{\text {Pyavg }} / 1000}
$$

\section{COST ESTIMATION FOR GRID TIE PV PLANT}

Multiple criteria decision analysis (MCDA) refers to making decisions in the presence of multiple, usually conflicting, criteria. In general, there exist two distinctive types of MCDA problems due to different problem settings: one type having a finite number of alternative solutions and the other an infinite number of solutions [9]. Normally in problems associated with selection and assessment, the number of alternative solutions is limited. In problems related to design, an attribute may take any value in a range. Therefore the potential alternative solutions could be infinite. If this is the case, the problem is referred to as multiple objective optimization problems instead of multiple attribute decision problems. In this paper research focus will be on the problems with a finite number of alternatives. Among many other MCDA algorithms TOPSIS is a powerful MCDA algorithm and it is used in this research investigation for optimal selection of PV panel.

\section{A. TOPSIS: MCDA TOOL}

The Technique for Order of Preference by Similarity to Ideal Solution (TOPSIS) is a multicriteria decision analysis tool, based on the concept that the chosen alternative should have the shortest geometric distance from the positive ideal solution (PIS) and the longest geometric distance from the negative ideal solution (NIS) [10]. It is a method of compensatory aggregation that compares a set of alternatives by identifying weights for each criterion, normalizing scores for each criterion and calculating the geometric distance between each alternative and the ideal alternative, which is the best score in each criterion. TOPSIS is used for ranking the alternatives as follows. A performance matrix is formed which consists of $m$ number of alternatives and $n$ number of alternatives, with the intersection of each alternative and criterion given as $X_{i j}$.

$$
\left(A_{i}\right)_{m \times 1}=\left(X_{i j}\right)_{m \times n}
$$

Where, $\left(A_{i}\right)_{m \times 1}=$ Matrix for alternatives $=\left[\begin{array}{c}A 1 \\ A 2 \\ \vdots \\ \vdots \\ A m\end{array}\right]$

Performance matrix $=$

$$
\left(X_{i j}\right)_{m \times n}=\left[\begin{array}{ccccc}
X_{11} & X_{12} & \cdots & \cdots & X_{1 n} \\
X_{21} & X_{22} & \cdots & \cdots & X_{2 n} \\
\vdots & \vdots & \cdots & \cdots & \vdots \\
\vdots & \vdots & \cdots & \cdots & \vdots \\
X_{m 1} & X_{m 2} & \cdots & \cdots & X_{m n}
\end{array}\right]
$$

Where, $\mathrm{i}=\{1,2, \ldots \ldots \ldots, m\}$ and $\mathrm{j}=\{1,2, \ldots \ldots \ldots, n\}$
Alternatives, $A=\left[\begin{array}{c}A 1 \\ A 2 \\ \vdots \\ \vdots \\ A m\end{array}\right]=\left[\begin{array}{ccccc}X_{11} & X_{12} & \cdots & \cdots & X_{1 n} \\ X_{21} & X_{22} & \cdots & \cdots & X_{2 n} \\ \vdots & \vdots & \cdots & \cdots & \vdots \\ \vdots & \vdots & \cdots & \cdots & \vdots \\ X_{m 1} & X_{m 2} & \cdots & \cdots & X_{m n}\end{array}\right]$

Step 1 : Normalization of performance matrix:

a) Determination of $\sqrt{\sum_{i=1}^{m} X_{i j}^{2}}$

b) Normalized performance matrix is given by: $r_{i j}=\frac{X_{i j}}{\sqrt{\sum_{i=1}^{m} X_{i j}^{2}}}$

Step 2 : Determination of the weighted normalized decision matrix:

a) Weight of criteria is given by $W_{j}=\left[\begin{array}{lllll}W_{1} & W_{2} & \ldots & \ldots & W_{n}\end{array}\right]$

b) Weighted normalized decision matrix, $V_{i j}=W_{j} \times r_{i j}$

Step 3 : Determination of ideal solution and negative ideal solution

a) Set of criteria having benefit attributes (i.e.; larger value is better) $=J_{+}$

b) Set of criteria having negative attributes (i.e.; smaller value is better) $=J_{-}$

c) Ideal solution:

$V_{j}^{*}=\quad\left\{\left\langle\max \left[\left(V_{i j} \mid i=1,2, \ldots . m\right)\left|j \epsilon J_{+}\right\rangle,\left\langle\min \left(V_{i j} \mid i=\right.\right.\right.\right.\right.$ $1,2, \ldots . m) j \epsilon J-$

d) Negative ideal solution:

$$
V_{j}^{\prime}=\left\{\left\langle\min \left(V_{i j} \mid i=1,2, \ldots . m\right) \mid j \epsilon J_{+}\right\rangle,\left\langle\operatorname { m a x } \left[\left( V_{i j} \mid i=\right.\right.\right.\right.
$$

Step 4 : Determination of separation of a target alternative from ideal solution .

Separation of a target alternative from ideal solution is given by $S_{i}^{*}=\sqrt{\sum_{j=1}^{n}\left(V_{j}^{*}-V_{i j}\right)^{2}}$

Step 5 : Determination of separation of target alternative from negative ideal solution.

Separation of a target alternative from negative ideal solution is given by $S_{i}^{\prime}=\sqrt{\sum_{j=1}^{n}\left(V_{j}^{\prime}-V_{i j}\right)^{2}}$

Step 6: Determination of the relative closeness of alternatives (similarity of alternative) to the ideal solution Relative closeness of alternatives to the ideal solution is given by $C_{i}^{*}=\frac{S_{i}^{*}}{\left(S_{i}^{*}+S_{i}^{\prime}\right)}$

Step 7: Identification of the best alternative (TOPSIS optimal solution).

Matrix for degree of closeness, $C_{i}^{*}=\left[\begin{array}{c}C_{1} \\ C_{2} \\ \vdots \\ \vdots \\ C_{m}\end{array}\right]$ 
Vol. 5, Issue 2, February 2017

Best alternative is one, for which $\mathrm{C}_{\mathrm{i}}^{*}=\max \left(\mathrm{C}_{\mathrm{i}}^{*}\right)$ index $=$ index of $\max \left(\mathrm{C}_{\mathrm{i}}^{*}\right)$

Best alternative $=A_{\text {index }}$.

\section{CASE STUDY}

The proposed method of optimal selection of PV panel has been applied to real data. Dhaka, Bangladesh is selected as PV plant location. Location data are collected from [11] using online software and data are listed in Table-I (Appendix). Solar data [12] of that location are listed in Table-II (Appendix). 15 no. of PV panels are selected and market price is collected from [13] on date $30^{\text {th }}$ November 2016 and 15 no. of alternatives are generated for these PV panels. Alternatives and panel data are listed in Table-III (Appendix). Design specified data are listed in Table-1.

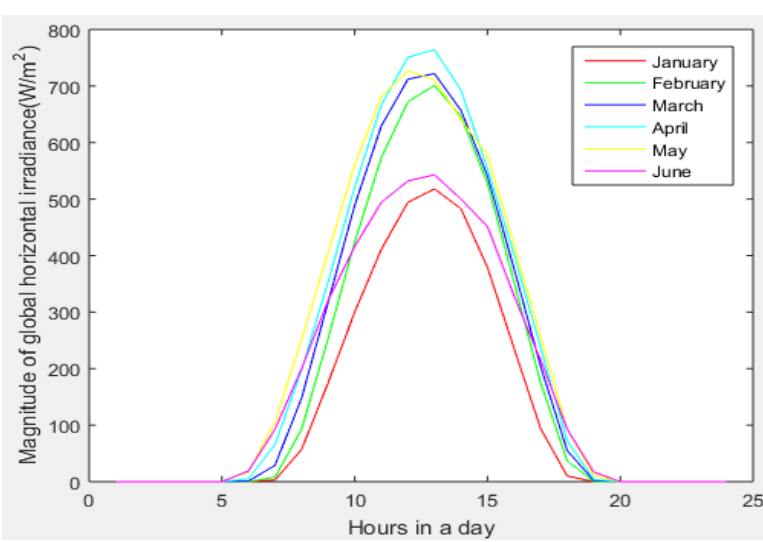

Fig. 2 Diurnal variation of global horizontal irradiance for January to June in the location of Dhaka, Bangladesh.

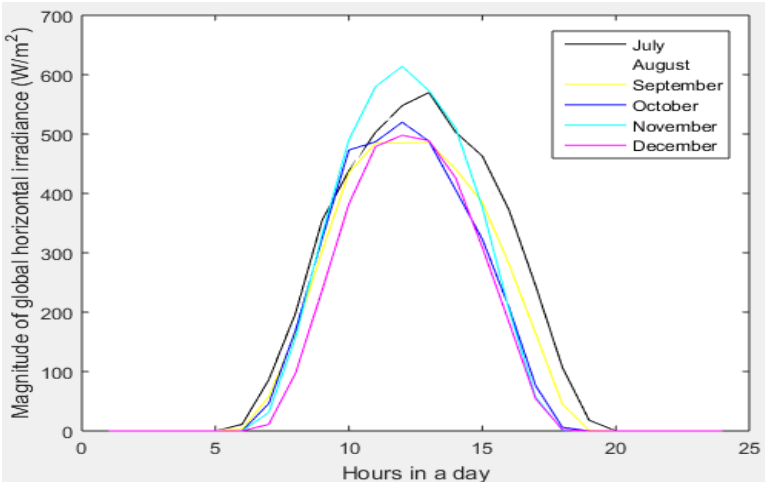

Fig. 3 Diurnal variation of global horizontal irradiance for July to December in the location of Dhaka, Bangladesh.

Using data which is listed in "Appendix" per unit electricity generation cost and required area of land are calculated for the PV electricity generation system as mentioned in diagram Fig.4.

Cost estimation data are listed in Table-2. Matlab@version2015a software is used for calculation in this case study. In this study, it is assumed that per unit prices of all items except PV panel for different alternatives are same.

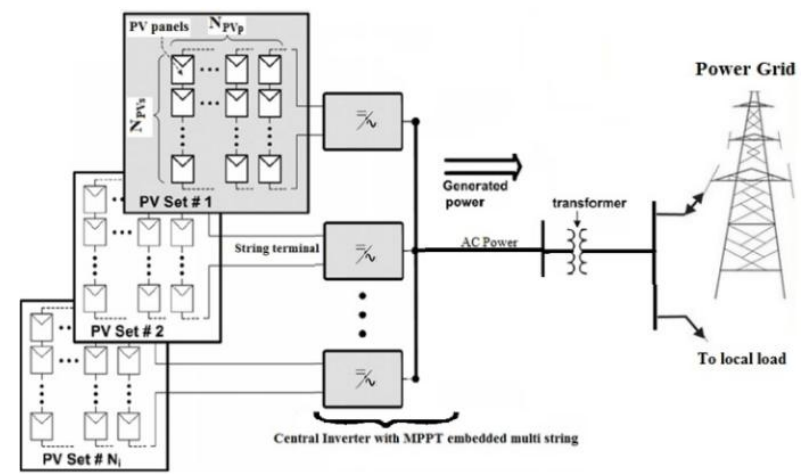

Fig.4 Battery less grid tie PV electricity generation system.

TABLE -1 DESIGN SPECIFIED DATA

\begin{tabular}{|l|l|}
\hline $\begin{array}{l}\text { Daily electricity production } \\
\text { target, } \mathrm{E}_{\text {reqday }}\end{array}$ & $10 \times 10^{5} \mathrm{Wh}$ \\
\hline Grid substation area, Area grid $_{\mathrm{d}}$ & $1 \mathrm{acre}$ \\
\hline Area exploitation factor, $\mathrm{f}_{\text {exploit }}$ & 0.56 \\
\hline Solar panel tilt angle, $\beta_{\text {tilt }}$ & $\begin{array}{l}23.5^{\circ} \text { (equal to } \\
\text { latitude) [14]. }\end{array}$ \\
\hline Solar panel azimuth angle, $\mathrm{A}_{\text {zpanel }}$ & $0^{\circ}$ \\
\hline
\end{tabular}

TABLE -2 COST ESTIMATION DATA

\begin{tabular}{|c|c|}
\hline $\mathrm{N}_{\text {lifepv }}$ & 25 years \\
\hline $\mathrm{N}_{\text {lifeinv }}$ & 5 years \\
\hline $\mathrm{N}_{\text {lifesupport }}$ & 25 years \\
\hline $\mathrm{N}_{\text {lifesubstation }}$ & 25 years \\
\hline $\mathrm{N}_{\text {lifeland }}$ & 25 years \\
\hline $\mathrm{N}_{\text {lifeproject }}$ & 25 years \\
\hline Price $_{\text {purinv }}$ & BDT 5/Watt \\
\hline Price $_{\text {supportpv }}$ & BDT $3000 / \mathrm{m}^{2}$ \\
\hline Price $_{\text {substation }}$ & BDT 15/Watt \\
\hline Price $_{\text {purland }}$ & BDT 300 lac/acre \\
\hline Price $_{\text {landdev }}$ & BDT:0.4 lac/acre \\
\hline$\%$ Salvage $\mathrm{pv}_{\mathrm{p}}$ & $20 \%$ \\
\hline$\%$ Salvage $_{\text {inverter }}$ & $20 \%$ \\
\hline$\%$ Salvage support & $20 \%$ \\
\hline$\%$ Salvage substation & $20 \%$ \\
\hline$\%$ Salvage land & $100 \%$ \\
\hline$\beta$ & 0.08 \\
\hline$\gamma$ & 0.12 \\
\hline$\Psi$ & 0.10 \\
\hline $\mathrm{N}_{\text {techstaff }}$ & 9 men \\
\hline $\mathrm{N}_{\text {secus taff }}$ & 9 men \\
\hline Salary $_{\text {techstaff }}$ & BDT 30000/man \\
\hline Salary $_{\text {secustaff }}$ & BDT 20000/man \\
\hline Price $_{\text {ompv }}$ & BDT 5/ Watt \\
\hline Price $_{\text {omsupport }}$ & BDT $150 / \mathrm{m}^{2}$ \\
\hline Price $_{\text {ominv }}$ & BDT 1/Watt \\
\hline Price $_{\text {omsubstation }}$ & BDT 2/Watt \\
\hline Price $_{\text {omland }}$ & BDT 0.5lac /acre \\
\hline
\end{tabular}


Vol. 5, Issue 2, February 2017

Applying equations (1) to (8) monthly average daily alternative. Using equations (17) to (43) per $\mathrm{kWh}$ production of electricity by each panel are calculated for electricity generation cost are calculated for each every month and then annual average energy production alternative. Performance values of criteria (Area of PV are calculated considering degradation of panel efficiency plant and per kWh cost) are obtained for every alternative. over life span by using equations (9) to (11). Applying Performance values of criteria for all alternatives are listed equations (12) to (16) required PV plant area for in Table-3.

generation of target PV electricity are calculated for each

TABLE-3 PERFORMANCE VALUES OF CRITERIA

\begin{tabular}{|c|c|c|c|}
\hline Alternatives & Model of Solar Panels & $\begin{array}{l}\text { Required area (in acres) } \\
\text { (Criterion-1) }\end{array}$ & $\begin{array}{l}\text { Per kWh electricity cost } \\
\text { (in BDT) (Criterion-2) }\end{array}$ \\
\hline 1 & $\begin{array}{l}\text { Astronergy VIOLIN CHSM6610P-260 } \\
\text { Silver Poly Solar Panel }\end{array}$ & 8.6732 & 15.2940 \\
\hline 2 & $\begin{array}{l}\text { Astronergy ASM6612P-315 Silver Poly } \\
\text { Solar Panel }\end{array}$ & 8.5896 & 15.3608 \\
\hline 3 & $\begin{array}{l}\text { SolarWorld SW285 Plus Black Mono } \\
\text { Solar Panel }\end{array}$ & 7.8154 & 14.4884 \\
\hline 4 & $\begin{array}{lllll}\begin{array}{l}\text { SolarWorld SW320 XL Silver Mono } \\
\text { Solar Panel }\end{array} & & \\
\end{array}$ & 8.3034 & 14.7438 \\
\hline 5 & $\begin{array}{l}\text { Suniva OPT280-60-4-100 Silver Mono } \\
\text { Solar Panel }\end{array}$ & 8.5082 & 15.7380 \\
\hline 6 & $\begin{array}{l}\text { Suniva OPT285-60-4-100 Silver Mono } \\
\text { Solar Panel }\end{array}$ & 8.1636 & 15.2945 \\
\hline 7 & $\begin{array}{l}\text { Topoint JTM190-72M } \\
\text { Solar Panel }\end{array}$ & 9.3624 & 15.8155 \\
\hline 8 & $\begin{array}{l}\text { Panasonic } 325 \text { watt Module } 96 \text { Cell HIT } \\
\text { - Black Solar Panel }\end{array}$ & 7.1501 & 14.6727 \\
\hline 9 & $\begin{array}{l}\text { Hyundai HiS-M260RG Black Frame, } \\
\text { White Backsheet Poly Solar Panel }\end{array}$ & 8.7669 & 15.4547 \\
\hline 10 & $\begin{array}{l}\text { LG } 320 \text { NeON, Mono, Black Frame - } \\
\text { LG320N1C-G4 Solar Panel }\end{array}$ & 7.2045 & 14.8358 \\
\hline 11 & LG 315N1C Black Mono Solar Panel & 7.3022 & 14.8452 \\
\hline 12 & LG 310N1C Black Mono Solar Panel & 7.3786 & 14.7873 \\
\hline 13 & $\begin{array}{l}\text { LG 300N1K Black on Black Mono } \\
\text { Solar Panel }\end{array}$ & 7.6490 & 14.9964 \\
\hline 14 & $\begin{array}{lll}\begin{array}{l}\text { Solarland SLP160S-12 } \\
\text { Solar Panel }\end{array} & \text { Silver Mono } \\
\end{array}$ & 8.8952 & 16.2725 \\
\hline 15 & $\begin{array}{l}\text { Solarland SLP150-12 Silver Poly Solar } \\
\text { Panel }\end{array}$ & 9.4369 & 16.6277 \\
\hline
\end{tabular}

\section{RESULT}

Performance values of two criteria which are required land area and per kWh electricity generation cost are listed for each alternative and a performance matrix is formed. Row of this matrix is the performance value for a particular alternative. Weighting of criteria is adopted to give preference of the criteria. The TOPSIS which is a MCDA algorithm is applied for ranking the alternatives. Best alternative has higher degree of closeness to the ideal solution and corresponding to the best alternative is the optimal PV panel. Result for ranking of alternatives considering equal weight of both criteria is shown in Fig. 5. Result for different weighing of criteria is given in appendix.

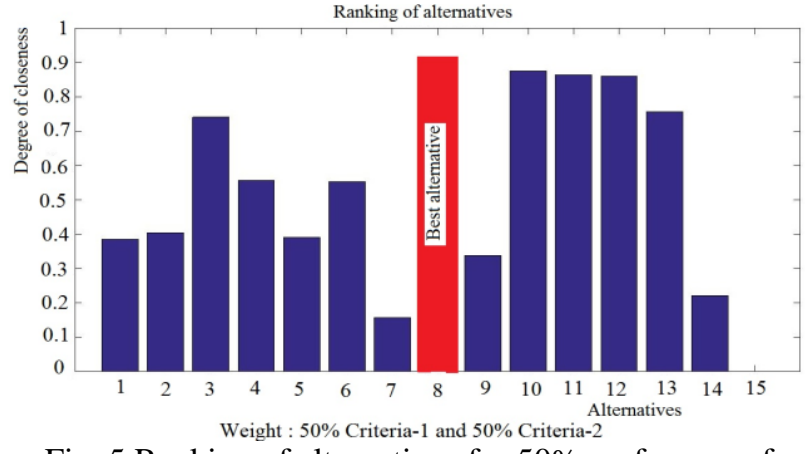

Fig. 5 Ranking of alternatives for $50 \%$ preference of criterion- 1 , and $50 \%$ preference of criterion- 2 . 
Vol. 5, Issue 2, February 2017

TABLE-4 RESULT FOR BEST ALTERNATIVE

\begin{tabular}{|l|l|l|l|}
\hline $\begin{array}{l}\text { Best } \\
\text { altern } \\
\text { ative }\end{array}$ & $\begin{array}{l}\text { Model of Solar } \\
\text { Panels }\end{array}$ & $\begin{array}{l}\text { Required } \\
\text { area (in } \\
\text { acres) } \\
\text { Criterion- } \\
1)\end{array}$ & $\begin{array}{l}\text { Per kWh } \\
\text { electricity } \\
\text { cost (in } \\
\text { BDT) } \\
\text { (Criterion- } \\
\text { 2) }\end{array}$ \\
\hline 8 & $\begin{array}{l}\text { Panasonic 325 } \\
\text { watt Module 96 } \\
\text { Cell HIT - Black } \\
\text { Solar Panel }\end{array}$ & 7.1501 & 14.6727 \\
\hline
\end{tabular}

\section{CONCLUSION}

Optimal selection of PV panel for grid tie PV power plant can be achieved by performing the proposed approach. In a highly dense country, land availability is a crisis and hence land usage should be reduced. Per unit electricity generation cost should be minimized for saving of revenue.

To install a large scale PV plant, these two major concerns should be taken into account. This proposed method is capable to reduce both land usage and electricity generation cost for a PV plant. This method gives decision makers and designer flexibility to insert new criteria and also allows inserting special weighing preference for specified criteria. The proposed method can be considered a viable guidance in the design process or policy making process.

\section{REFERENCES}

11] The Organization for Economic Co-operation and Development, "OECD Factbook 2015-2016," Economic, Environmental and Social Statistics 2015-16. [Online]. Available:http://www.oecd.org/publications/oecd-factbook18147364.htm

[2] Wohlgemuth,John H., "Standards for PV Modules and Components - Recent Developments and Challenges," 27th European Photovoltaic Solar Energy Conference and Exhibition, Frankfurt, Germany, September 24-28, 2012.

[3] M. Gulin, M. Va`sak, and N. Peri'c, "Dynamical optimal positioning of a photovoltaic panel in all weather conditions," Applied Energy, vol. 108, no. 0, pp. 429-438, August 2013.

[4] Gulin, Marko, Mario Vašak, and Mato Baotic. "Estimation of the global solar irradiance on tilted surfaces." 17th International Conference on Electrical Drives and Power Electronics (EDPE 2013). 2013.

[5] V. Badescu, "3D isotropic approximation for solar diffuse irradiance ontilted surfaces," Renewable Energy, vol. 26, no. 2, pp. 221-233, June 2002.

[6] H.R. Ghosh, N.C. Bhowmik and M. Hussain, "Determining seasonal optimum tilt angles, solar radiations on variously oriented, single and double axis tracking surfaces at Dhaka, Renewable Energy, Volume 35, Issue 6, June 2010, Pages 1292-1297

[7] Alsayed, M., Cacciato, M., Scarcella, G. and Scelba, G., "Multicriteria Optimal Sizing of Photovoltaic-Wind Turbine Grid Connected Systems ," IEEE Transactions on Energy Conversion ,Vol.28, Issue. 2 , pp. 370-379,2013.

[8] Wang, Lingfeng and Singh, Chanan, "Multicriteria Design of Hybrid Power Generation Systems Based on a Modified Particle
Swarm Optimization Algorithm," IEEE Transactions on Energy Conversion, Vol.24, Issue 1, pp. 163 - 172, 2009.

[9] Dr. Ling Xu and Dr. Jian-Bo Yang, "Introduction to Multi-Criteria Decision Making and the Evidential Reasoning Approach", Manchester School of Management, University of Manchester Institute of Science and Technology, Working Paper No. 0106,May 2001

[10] Assari, A., Mahesh, T., and Assari, E., "Role of public participation in sustainability of historical city: usage of TOPSIS method,'Indian Journal of Science and Technology, Vol.5, Issue. 3, pp. 2289-2294, 2012.

11] http://www.sunearthtools.com/dp/tools/pos_sun.php?lang=en

[12] Prof. (retd) Muhtasham Hussain, Md. Shafiuzzaman Khan Khadem and Himangshu Ranjan Ghosh, "Country Report of Solar and Wind Energy Resource Assessment (SWERA) - Bangladesh," Supported by, United Nations Environment Programme (UNEP) and Global Environment Facility (GEF),2007.

[13] http://www.wholesalesolar.com/

[14] Md. Saifur Rahman et al., "Solar Energy and Solar Electricity," Solar Home System, first edition, Dhaka, Bangladesh: Department of Electrical and Electronic Engineering, BUET, 2013, ch. 1, sec. 1.14 , pp. $45-46$.

\section{BIOGRAPHIES}

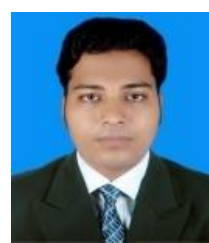

Md. Abubokar Talukdar received the B.Sc in Electrical and Electronic Engineering and M.S in Nuclear Engineering from "Chittagong University of Engineering and Technology" and "University of Dhaka" respectively. $\mathrm{He}$ is perusing $\mathrm{M} . \mathrm{Sc}$ in Electrical and Electronic Engineering in Bangladesh University of Engineering and Technology. He worked as a lecturer in Electrical, Electronics and Telecommunication Engineering at Dhaka International University, Bangladesh from 2011 to 2013 . He is currently working as an electrical engineer in Bangladesh Power Development Board, Dhaka.

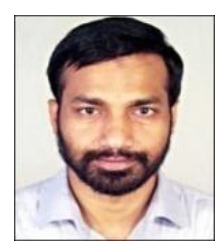

Hamidur Rahman is currently working as an associate professor in Electrical and Electronic Engineering in Bangladesh University of Engineering and Technology. His research interests are renewable energy, power system, and control system engineering. $\mathrm{He}$ is currently supervising several post graduate researches on renewable energy.

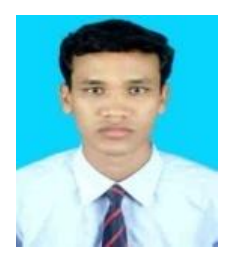

Pejush Chandra Sarker is currently working as a lecturer in Electrical and Electronic Engineering in Rajshahi University of Engineering and Technology, Bangladesh. His research interests are Electrical Machines, Control System, Power System and Renewable Energy. He is an author of several international journal papers. He was awarded with "Prime Minister Gold Medal-2010" by the government of Bangladesh for his academic excellence. 
IJIREEICE

International Journal of Innovative Research in Electrical, Electronics, Instrumentation and Control Engineering

ISO 3297:2007 Certified

Vol. 5, Issue 2, February 2017

\section{APPENDIX}

\section{TABLE I LOCATION DATA}

\begin{tabular}{|c|c|c|c|c|c|c|c|c|c|c|c|c|}
\hline \multicolumn{13}{|c|}{ me of location: Dhaka, Bangladesh; Latitude, $\varnothing=23.81^{\circ} \mathrm{N}$, Longitude, long $=90.41^{\circ} \mathrm{E}, \mathrm{GMT}=+6$, Ground albedo, $\rho=0.2$} \\
\hline \multirow{2}{*}{$\begin{array}{l}\text { Hours } \\
\text { in a } \\
\text { day }\end{array}$} & \multicolumn{12}{|c|}{ Sun Azimuth angle, $A_{\text {zsun }}$ / Sun Altitude angle, $\Theta_{A}$ in degree for middle day of different months in a year } \\
\hline & $\begin{array}{l}15^{\text {th }} \\
\text { Jan }\end{array}$ & $14^{\text {th }} \mathrm{Feb}$ & $\begin{array}{l}15^{\text {th }} \\
\text { Mar }\end{array}$ & $\begin{array}{l}15^{\text {th }} \\
\text { Apr }\end{array}$ & $\begin{array}{l}15^{\text {th }} \\
\text { May }\end{array}$ & $15^{\text {th }}$ Jun & $15^{\text {th }} \mathrm{Jul}$ & $\begin{array}{l}15^{\text {th }} \\
\text { Aug }\end{array}$ & $\begin{array}{l}15^{\text {th }} \\
\text { Sep }\end{array}$ & $15^{\text {th }}$ Oct & $\begin{array}{l}15^{\text {th }} \\
\text { Nov }\end{array}$ & $\begin{array}{l}15^{\text {th }} \\
\text { Dec }\end{array}$ \\
\hline 1:00 & $\begin{array}{l}80.91 / \\
-77.59\end{array}$ & $\begin{array}{l}49.10 /- \\
74.66\end{array}$ & $\begin{array}{l}32.37 /- \\
64.86\end{array}$ & $\begin{array}{l}25.87 /- \\
53.21\end{array}$ & $\begin{array}{l}21.86 /- \\
44.45\end{array}$ & $\begin{array}{l}18.60 /- \\
40.6\end{array}$ & $\begin{array}{l}17.72 /- \\
42.69\end{array}$ & $\begin{array}{l}21.68 /- \\
49.66\end{array}$ & $\begin{array}{l}33.25 /- \\
58.69\end{array}$ & $\begin{array}{l}52.99 /- \\
66.29\end{array}$ & $\begin{array}{l}77.15 /- \\
71.28\end{array}$ & $\begin{array}{l}91.31 /- \\
74.73\end{array}$ \\
\hline 2:00 & $\begin{array}{l}90.08 / \\
-63.92\end{array}$ & $\begin{array}{l}72.40 /- \\
62.54\end{array}$ & $\begin{array}{l}55.66 /- \\
55.18\end{array}$ & $\begin{array}{l}44.98 /- \\
45.16\end{array}$ & $\begin{array}{l}38.32 /- \\
37.51\end{array}$ & $\begin{array}{l}34.18 /- \\
34.45\end{array}$ & $\begin{array}{l}34.10 /- \\
36.66\end{array}$ & $\begin{array}{l}40.10 /- \\
42.56\end{array}$ & $\begin{array}{l}53.19 /- \\
49.21\end{array}$ & $\begin{array}{l}70.52 /- \\
54.14\end{array}$ & $\begin{array}{l}87.19 /- \\
57.68\end{array}$ & $\begin{array}{l}95.41 /- \\
61.04\end{array}$ \\
\hline 3:00 & $\begin{array}{l}95.17 / \\
-50.22\end{array}$ & $\begin{array}{l}82.82 /- \\
49.12\end{array}$ & $\begin{array}{l}69.12 /- \\
42.97\end{array}$ & $\begin{array}{l}58.19 / 3 \\
4.36\end{array}$ & $\begin{array}{l}50.70 /- \\
27.85\end{array}$ & $\begin{array}{l}46.34 /- \\
25.55\end{array}$ & $\begin{array}{l}46.80 /- \\
27.73\end{array}$ & $\begin{array}{l}53.45 /- \\
32.53\end{array}$ & $\begin{array}{l}65.88 /- \\
37.36\end{array}$ & $\begin{array}{l}80.40 /- \\
40.86\end{array}$ & $\begin{array}{l}93.23 /- \\
43.97\end{array}$ & $\begin{array}{l}99.09 /- \\
47.43\end{array}$ \\
\hline 4:00 & $\begin{array}{l}99.57 / \\
-36.61\end{array}$ & $\begin{array}{l}89.71 /- \\
35.43\end{array}$ & $\begin{array}{l}78.06 / 2 \\
9.8\end{array}$ & $\begin{array}{l}67.63 /- \\
22.13\end{array}$ & & $\begin{array}{l}55.61 /- \\
14.87\end{array}$ & $\begin{array}{l}56.41 /- \\
16.96\end{array}$ & $\begin{array}{l}\text { 63.19/- } \\
20.85\end{array}$ & $\begin{array}{l}74.77 /- \\
24.44\end{array}$ & $\begin{array}{l}87.49 /- \\
27.22\end{array}$ & $\begin{array}{l}98.28 /- \\
30.33\end{array}$ & $\begin{array}{l}102.91 / \\
-33.9\end{array}$ \\
\hline 5:00 & $\begin{array}{l}104.0 / \\
-23.18\end{array}$ & $\begin{array}{l}95.44 /- \\
21.72\end{array}$ & $\begin{array}{l}84.99 /- \\
16.22\end{array}$ & $\begin{array}{l}74.94 /- \\
9.12\end{array}$ & $\begin{array}{l}67.18 /- \\
4.24\end{array}$ & $\begin{array}{l}62.81 /- \\
3.07\end{array}$ & $\begin{array}{l}63.83 /- \\
5.05\end{array}$ & $\begin{array}{l}70.69 /- \\
8.22\end{array}$ & $\begin{array}{l}81.76 /- \\
11.01\end{array}$ & $\begin{array}{l}93.54 /- \\
13.51\end{array}$ & $\begin{array}{l}103.25 / \\
-16.9\end{array}$ & $\begin{array}{l}107.15 / \\
-20.7\end{array}$ \\
\hline 6:00 & & $\begin{array}{l}100.98 /- \\
8.14\end{array}$ & $\begin{array}{l}91.14 /- \\
2.45\end{array}$ & $\begin{array}{l}81.13 / 4 . \\
31\end{array}$ & $\begin{array}{l}73.07 / 8 \\
67\end{array}$ & $\begin{array}{l}68.58 / 9 \\
44\end{array}$ & $\begin{array}{l}69.8 /- \\
7.56\end{array}$ & $\begin{array}{l}76.9 / 4 . \\
95\end{array}$ & & $\begin{array}{l}99.46 / 0 . \\
12\end{array}$ & $\begin{array}{l}108.66 / \\
-3.67\end{array}$ & $\begin{array}{l}112.06 / \\
-7.80\end{array}$ \\
\hline 7:00 & & $\begin{array}{l}6.97 / \\
8 \\
\end{array}$ & $\begin{array}{l}29 / 1 \\
9\end{array}$ & $\begin{array}{l}86.92 / 1 \\
7.96\end{array}$ & $21 / 2$ & $\begin{array}{l}73.38 / 2 \\
2.41\end{array}$ & $\begin{array}{l}74.84 / 2 \\
0.64\end{array}$ & & & $\begin{array}{l}105.92 / \\
13.5\end{array}$ & $\begin{array}{l}4.99 / \\
7\end{array}$ & $\begin{array}{l}117.98 / \\
4.64\end{array}$ \\
\hline 8:00 & & $\begin{array}{l}4.03 / \\
05\end{array}$ & & $\begin{array}{l}92.99 / 3 \\
1.69\end{array}$ & $5 / 3$ & $\begin{array}{l}77.54 / 3 \\
5.69\end{array}$ & $\begin{array}{l}79.34 / 3 \\
4.01\end{array}$ & & & & $\begin{array}{l}.88 / \\
88\end{array}$ & $2^{4 / 1}$ \\
\hline 9:00 & & $\begin{array}{l}123.05 / \\
30.12 \\
\end{array}$ & $\begin{array}{l}112.91 / \\
37.7 \\
\end{array}$ & $\begin{array}{l}100.32 / \\
45.32 \\
\end{array}$ & $\begin{array}{l}16 / 4 \\
9 \\
\end{array}$ & $\begin{array}{l}81.31 / 4 \\
9.18 \\
\end{array}$ & $\begin{array}{l}83.68 / 4 \\
7.57 \\
\end{array}$ & & & $\begin{array}{l}04 / \\
3 \\
\end{array}$ & $\begin{array}{l}133.21 / \\
31.9 \\
\end{array}$ & $\begin{array}{l}.01 / \\
32\end{array}$ \\
\hline 10:00 & & $\begin{array}{l}135.33 / \\
40.80\end{array}$ & $\begin{array}{l}125.4 / 4 \\
9.73\end{array}$ & $\begin{array}{l}111.17 / \\
58.55\end{array}$ & $\begin{array}{l}75 / 6 \\
0\end{array}$ & $\begin{array}{l}84.94 / 6 \\
2.80\end{array}$ & $\begin{array}{l}88.46 / 6 \\
1.26\end{array}$ & & & & $\begin{array}{l}7.08 / \\
73\end{array}$ & $\begin{array}{l}7.59 / \\
43\end{array}$ \\
\hline 11:00 & & $\begin{array}{l}2.51 / \\
.95\end{array}$ & & $\begin{array}{l}132.47 / \\
70.34\end{array}$ & $3^{2 / 7}$ & $\begin{array}{l}89.09 / 7 \\
6.5 \\
\end{array}$ & $\begin{array}{l}5.84 / 7 \\
96\end{array}$ & & & & $\begin{array}{l}95 / \\
22\end{array}$ & $\begin{array}{l}.58 / \\
44\end{array}$ \\
\hline 12:00 & & $\begin{array}{l}174.93 / \\
52.87 \\
\end{array}$ & & $\begin{array}{l}181.67 / \\
76.12 \\
\end{array}$ & & & & & & & $\begin{array}{l}.95 / \\
99\end{array}$ & $\begin{array}{l}182.0 / 4 \\
2.88\end{array}$ \\
\hline 13:00 & & $\begin{array}{l}198.64 / \\
51.23 \\
\end{array}$ & $\begin{array}{l}208.3 / 6 \\
1.24 \\
\end{array}$ & $\begin{array}{l}229.28 / \\
69.80 \\
\end{array}$ & $\begin{array}{l}255.50 / \\
74.08 \\
\end{array}$ & $\begin{array}{l}271.11 / \\
76.0\end{array}$ & $\begin{array}{l}262.26 / \\
76.96 \\
\end{array}$ & & & $92 /$ & $\begin{array}{l}205.56 / \\
43.61 \\
\end{array}$ & $\begin{array}{l}200.09 / \\
40.22 \\
\end{array}$ \\
\hline 14:00 & $\begin{array}{l}213.5 / \\
37.32\end{array}$ & $\begin{array}{l}218.20 / \\
44.65 \\
\end{array}$ & $\begin{array}{l}230.72 / \\
52.41\end{array}$ & $\begin{array}{l}249.69 / \\
57.88 \\
\end{array}$ & $\begin{array}{l}266.71 / \\
60.51\end{array}$ & $\begin{array}{l}275.20 / \\
62.31 \\
\end{array}$ & $\begin{array}{l}270.67 / \\
63.26 \\
\end{array}$ & $\begin{array}{l}255.54 \\
/ 66.62\end{array}$ & & 53 & $\begin{array}{l}221.23 / \\
36\end{array}$ & $\begin{array}{l}215.37 / \\
24.7\end{array}$ \\
\hline 15:00 & $\begin{array}{l}2 \\
2\end{array}$ & $\begin{array}{l}2.37 / \\
86\end{array}$ & & $\begin{array}{l}26 \\
44 \\
\end{array}$ & & & & & & & $\begin{array}{l}2.94 / \\
.91\end{array}$ & $\begin{array}{l}7.25 / \\
.70\end{array}$ \\
\hline 16:00 & & $\begin{array}{l}242.59 / \\
23.28 \\
\end{array}$ & & $\begin{array}{l}267.49 / \\
30.99 \\
\end{array}$ & $\begin{array}{l}277.89 / \\
33.14 \\
\end{array}$ & $282.62 /$ & & & & & $\begin{array}{l}241.74 / \\
14.34 \\
\end{array}$ & $\begin{array}{l}236.32 / \\
14.90 \\
\end{array}$ \\
\hline 17:00 & $\begin{array}{l}243.8 / \\
5.86 \\
\end{array}$ & $\begin{array}{l}250.37 / \\
10.70 \\
\end{array}$ & $\begin{array}{l}261.30 / \\
14.94 \\
\end{array}$ & $\begin{array}{l}273.54 / \\
17.28 \\
\end{array}$ & $\begin{array}{l}282.76 / \\
19.65 \\
\end{array}$ & $\begin{array}{l}286.80 / \\
21.94 \\
\end{array}$ & $\begin{array}{l}284.34 / \\
22.56 \\
\end{array}$ & $\begin{array}{l}276.87 \\
/ 19.69 \\
\end{array}$ & & $\begin{array}{l}257.46 / \\
6.39 \\
\end{array}$ & $\begin{array}{l}248.64 / \\
1.88 \\
\end{array}$ & $\begin{array}{l}243.37 / \\
2.03 \\
\end{array}$ \\
\hline 18:00 & $249.8 /$ & $\begin{array}{l}256.75 /- \\
2.45\end{array}$ & $\begin{array}{l}267.58 / \\
0.89 \\
\end{array}$ & $\begin{array}{l}279.35 / \\
3.65 \\
\end{array}$ & $288.06 /$ & $\begin{array}{l}291.63 / \\
8.98 \\
\end{array}$ & $\begin{array}{l}289.34 / \\
9.43 \\
\end{array}$ & $\begin{array}{l}282.42 \\
/ 6.15 \\
\end{array}$ & $\begin{array}{l}273.18 \\
/-0.39 \\
\end{array}$ & $\begin{array}{l}263.52 / \\
-7.15 \\
\end{array}$ & $\begin{array}{l}254.36 / \\
-11.1 \\
\end{array}$ & $\begin{array}{l}249.04 / \\
-10.5 \\
\end{array}$ \\
\hline 19:00 & $\begin{array}{l}254.9 / \\
-19.82 \\
\end{array}$ & $\begin{array}{l}262.44 /- \\
15.9\end{array}$ & 273.7/- & $\begin{array}{l}285.61 / \\
-9.74 \\
\end{array}$ & $\begin{array}{l}294.10 / \\
-6.38 \\
\end{array}$ & $297.44 /$ & $295.13 /$ & $\begin{array}{l}288.52 \\
/-7.08 \\
\end{array}$ & $\begin{array}{l}279.44 \\
/-14.0 \\
\end{array}$ & $\begin{array}{l}269.38 / \\
-20.9 \\
\end{array}$ & $\begin{array}{l}259.43 / \\
24.51 \\
\end{array}$ & $\begin{array}{l}253.77 / \\
-23.5 \\
\end{array}$ \\
\hline 20:00 & $\begin{array}{l}259.5 / \\
-19.82 \\
\end{array}$ & $\begin{array}{l}268.06 /- \\
29.6 \\
\end{array}$ & $\begin{array}{l}280.41 / \\
-26.4 \\
\end{array}$ & $\begin{array}{l}293.04 / \\
-22.7 \\
\end{array}$ & $\begin{array}{l}301.61 / \\
-18.5 \\
\end{array}$ & $\begin{array}{l}304.7 /- \\
15.26 \\
\end{array}$ & $\begin{array}{l}302.3 /- \\
15.33 \\
\end{array}$ & $\begin{array}{l}295.84 \\
-19.8 \\
\end{array}$ & $\begin{array}{l}286.69 \\
/-27.4 \\
\end{array}$ & $\begin{array}{l}275.77 / \\
-34.6 \\
\end{array}$ & $\begin{array}{l}264.32 / \\
-38.1 \\
\end{array}$ & $\begin{array}{l}257.89 / \\
-36.8 \\
\end{array}$ \\
\hline 21:00 & $\begin{array}{l}263.9 / \\
-46.76 \\
\end{array}$ & $\begin{array}{l}274.38 /- \\
43.3\end{array}$ & $\begin{array}{l}288.77 / \\
-39.7\end{array}$ & $\begin{array}{l}302.67 / \\
-34.8\end{array}$ & $\begin{array}{l}311.36 / \\
-29.6\end{array}$ & $\begin{array}{l}314.07 / \\
-25.9 \\
\end{array}$ & $\begin{array}{l}311.52 / \\
-26.3 \\
\end{array}$ & $\begin{array}{l}305.29 \\
/-31.6\end{array}$ & $\begin{array}{l}296.13 \\
/-40.2\end{array}$ & $\begin{array}{l}283.91 / \\
-48.1\end{array}$ & $\begin{array}{l}269.66 / \\
-51.8\end{array}$ & $\begin{array}{l}261.64 / \\
-50.3 \\
\end{array}$ \\
\hline 22:00 & $\begin{array}{r}268.8 / \\
-60.45 \\
\end{array}$ & $\begin{array}{l}282.97 /- \\
56.9\end{array}$ & $300.86 /$ & $\begin{array}{l}316.16 / \\
-45.5 \\
\end{array}$ & $324.4 /-$ & $326.3 /-$ & $\begin{array}{l}323.72 / \\
-35.6 \\
\end{array}$ & $\begin{array}{l}318.23 \\
/-41.9 \\
\end{array}$ & $\begin{array}{l}309.99 \\
/-51.8\end{array}$ & $\begin{array}{l}296.7 /- \\
60.99 \\
\end{array}$ & $\begin{array}{l}277.05 / \\
-65.5 \\
\end{array}$ & $\begin{array}{l}265.3 /- \\
63.96 \\
\end{array}$ \\
\hline 23:00 & $\begin{array}{l}276.4 / \\
-74.15\end{array}$ & $\begin{array}{l}298.88 /- \\
69.7\end{array}$ & $\begin{array}{l}231.14 / \\
-62.6\end{array}$ & $\begin{array}{l}335.57 / \\
-53.2\end{array}$ & $\begin{array}{l}341.54 / \\
-45.1\end{array}$ & $\begin{array}{l}342.03 / \\
-40.7\end{array}$ & $\begin{array}{l}339.6 /- \\
42.18\end{array}$ & $\begin{array}{l}336.19 \\
/-49.4\end{array}$ & $\begin{array}{l}332.08 \\
/-60.5\end{array}$ & $\begin{array}{l}323.04 / \\
-71.7\end{array}$ & $\begin{array}{l}294.87 / \\
-78.8\end{array}$ & $\begin{array}{l}269.6 /- \\
77.66\end{array}$ \\
\hline 0:00 & $\begin{array}{l}325.5 / \\
-86.98\end{array}$ & $\begin{array}{l}343.55 /- \\
79.4\end{array}$ & $\begin{array}{l}355.01 / \\
68.26\end{array}$ & $\begin{array}{l}0.67 /- \\
56.43\end{array}$ & $\begin{array}{l}1.84 \\
/ 47.31\end{array}$ & $\begin{array}{l}0.37 /- \\
42.88\end{array}$ & $\begin{array}{l}358.58 / \\
-44.7\end{array}$ & $\begin{array}{l}358.84 \\
/-52.1\end{array}$ & $\begin{array}{l}3.48 / \\
-63.11\end{array}$ & $\begin{array}{l}14.5 / \\
-74.24\end{array}$ & $\begin{array}{l}37.51 /- \\
83.34\end{array}$ & $\begin{array}{l}70.53 /- \\
88.38\end{array}$ \\
\hline
\end{tabular}

TABLE II SOLAR GHI AND DHI DATA

Monthly average hourly solar GHI $\left(\mathrm{W} / \mathrm{m}^{2}\right)$ data

\begin{tabular}{|c|c|c|c|c|c|c|c|c|c|c|c|c|}
\hline \multicolumn{10}{|c|}{ Monthly average hourly solar GHI $\left(\mathrm{W} / \mathrm{m}^{2}\right)$ data } \\
\hline Hours in a day & Jan & Feb & Mar & Apr & May & Jun & Jul & Aug & Sep & Oct & Nov & Dec \\
\hline 1 & 0 & 0 & 0 & 0 & 0 & 0 & 0 & 0 & 0 & 0 & 0 & 0 \\
\hline
\end{tabular}


IJIREEICE

International Journal of Innovative Research in Electrical, Electronics, Instrumentation and Control Engineering

ISO 3297:2007 Certified

Vol. 5, Issue 2, February 2017

\begin{tabular}{|c|c|c|c|c|c|c|c|c|c|c|c|c|}
\hline 2 & 0 & 0 & 0 & 0 & 0 & 0 & 0 & 0 & 0 & 0 & 0 & 0 \\
\hline 3 & 0 & 0 & 0 & 0 & 0 & 0 & 0 & 0 & 0 & 0 & 0 & 0 \\
\hline 4 & 0 & 0 & 0 & 0 & 0 & 0 & 0 & 0 & 0 & 0 & 0 & 0 \\
\hline 5 & 0 & 0 & 0 & 0 & 0 & 0 & 0 & 0 & 0 & 0 & 0 & 0 \\
\hline 6 & 0 & 0 & 1 & 5 & 17 & 19 & 11 & 7 & 3 & 0 & 0 & 0 \\
\hline 7 & 3 & 8 & 29 & 66 & 106 & 93 & 86 & 66 & 58 & 46 & 31 & 11 \\
\hline 8 & 57 & 93 & 148 & 198 & 252 & 200 & 198 & 180 & 165 & 169 & 157 & 97 \\
\hline 9 & 175 & 254 & 318 & 354 & 406 & 321 & 355 & 288 & 303 & 324 & 331 & 237 \\
\hline 10 & 300 & 424 & 489 & 521 & 561 & 416 & 438 & 433 & 435 & 473 & 490 & 382 \\
\hline 11 & 411 & 573 & 629 & 666 & 681 & 494 & 503 & 514 & 485 & 487 & 580 & 479 \\
\hline 12 & 494 & 672 & 712 & 751 & 727 & 532 & 548 & 537 & 485 & 520 & 614 & 498 \\
\hline 13 & 518 & 701 & 722 & 764 & 711 & 543 & 570 & 535 & 486 & 488 & 573 & 489 \\
\hline 14 & 483 & 646 & 657 & 693 & 641 & 500 & 503 & 482 & 441 & 406 & 510 & 426 \\
\hline 15 & 379 & 528 & 541 & 553 & 577 & 451 & 463 & 453 & 385 & 323 & 377 & 309 \\
\hline 16 & 236 & 353 & 377 & 402 & 419 & 329 & 372 & 356 & 281 & 208 & 204 & 183 \\
\hline 17 & 94 & 175 & 204 & 237 & 257 & 215 & 244 & 231 & 164 & 76 & 57 & 54 \\
\hline 18 & 10 & 37 & 55 & 72 & 93 & 93 & 107 & 89 & 45 & 6 & 1 & 2 \\
\hline 19 & 0 & 0 & 2 & 4 & 11 & 17 & 18 & 8 & 1 & 0 & 0 & 0 \\
\hline 20 & 0 & 0 & 0 & 0 & 0 & 0 & 0 & 0 & 0 & 0 & 0 & 0 \\
\hline 21 & 0 & 0 & 0 & 0 & 0 & 0 & 0 & 0 & 0 & 0 & 0 & 0 \\
\hline 22 & 0 & 0 & 0 & 0 & 0 & 0 & 0 & 0 & 0 & 0 & 0 & 0 \\
\hline 23 & 0 & 0 & 0 & 0 & 0 & 0 & 0 & 0 & 0 & 0 & 0 & 0 \\
\hline 24 & 0 & 0 & 0 & 0 & 0 & 0 & 0 & 0 & 0 & 0 & 0 & 0 \\
\hline \multicolumn{13}{|c|}{ Monthly average hourly solar DIF $\left(\mathrm{W} / \mathrm{m}^{2}\right)$ data } \\
\hline Hours in a day & Jan & Feb & Mar & Apr & May & Jun & Jul & Aug & Sep & Oct & Nov & Dec \\
\hline 1 & 0 & 0 & 0 & 0 & 0 & 0 & 0 & 0 & 0 & 0 & 0 & 0 \\
\hline 2 & 0 & 0 & 0 & 0 & 0 & 0 & 0 & 0 & 0 & 0 & 0 & 0 \\
\hline 3 & 0 & 0 & 0 & 0 & 0 & 0 & 0 & 0 & 0 & 0 & 0 & 0 \\
\hline 4 & 0 & 0 & 0 & 0 & 0 & 0 & 0 & 0 & 0 & 0 & 0 & 0 \\
\hline 5 & 0 & 0 & 0 & 0 & 0 & 0 & 0 & 0 & 0 & 0 & 0 & 0 \\
\hline 6 & 0 & 0 & 1 & 5 & 16 & 18 & 11 & 6 & 3 & 0 & 0 & 0 \\
\hline 7 & 3 & 7 & 27 & 58 & 90 & 80 & 70 & 58 & 55 & 37 & 23 & 10 \\
\hline 8 & 47 & 70 & 109 & 147 & 183 & 156 & 145 & 140 & 137 & 108 & 87 & 59 \\
\hline 9 & 117 & 146 & 189 & 238 & 253 & 228 & 226 & 217 & 229 & 172 & 137 & 109 \\
\hline 10 & 172 & 205 & 244 & 308 & 322 & 281 & 287 & 292 & 279 & 238 & 176 & 145 \\
\hline 11 & 220 & 250 & 281 & 350 & 356 & 325 & 318 & 343 & 327 & 248 & 205 & 171 \\
\hline 12 & 250 & 274 & 297 & 372 & 381 & 339 & 349 & 350 & 333 & 263 & 223 & 194 \\
\hline 13 & 257 & 264 & 306 & 367 & 375 & 348 & 356 & 342 & 304 & 268 & 217 & 208 \\
\hline 14 & 240 & 254 & 276 & 339 & 345 & 317 & 295 & 319 & 269 & 219 & 206 & 193 \\
\hline 15 & 199 & 221 & 245 & 284 & 303 & 282 & 250 & 270 & 259 & 173 & 167 & 156 \\
\hline 16 & 139 & 170 & 191 & 217 & 238 & 215 & 211 & 224 & 187 & 122 & 110 & 105 \\
\hline 17 & 69 & 104 & 127 & 151 & 164 & 152 & 149 & 157 & 115 & 55 & 43 & 40 \\
\hline 18 & 9 & 30 & 46 & 60 & 77 & 75 & 82 & 68 & 38 & 5 & 1 & 2 \\
\hline 19 & 0 & 0 & 1 & 4 & 12 & 15 & 16 & 7 & 1 & 0 & 0 & 0 \\
\hline 20 & 0 & 0 & 0 & 0 & 0 & 0 & 0 & 0 & 0 & 0 & 0 & 0 \\
\hline 21 & 0 & 0 & 0 & 0 & 0 & 0 & 0 & 0 & 0 & 0 & 0 & 0 \\
\hline 22 & 0 & 0 & 0 & 0 & 0 & 0 & 0 & 0 & 0 & 0 & 0 & 0 \\
\hline 23 & 0 & 0 & 0 & 0 & 0 & 0 & 0 & 0 & 0 & 0 & 0 & 0 \\
\hline 24 & 0 & 0 & 0 & 0 & 0 & 0 & 0 & 0 & 0 & 0 & 0 & 0 \\
\hline
\end{tabular}

12:00 represents the period between 11:00 to 12:00. 
IJIREEICE

International Journal of Innovative Research in Electrical, Electronics, Instrumentation and Control Engineering

ISO 3297:2007 Certified

Vol. 5, Issue 2, February 2017

TABLE III ALTERNATIVES AND PV PANEL DATA

\begin{tabular}{|c|c|c|c|c|c|c|c|c|c|c|c|c|c|c|c|}
\hline 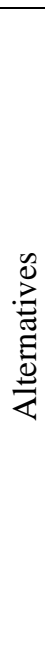 & 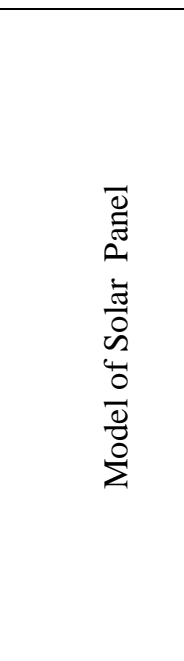 & 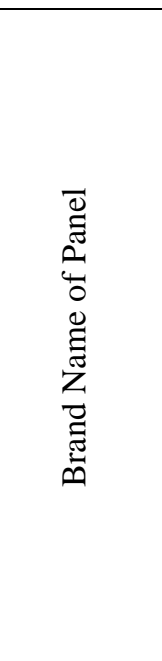 & 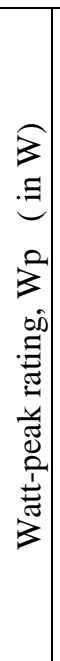 & 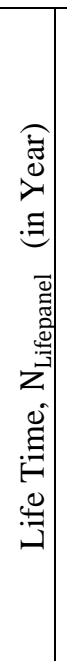 & 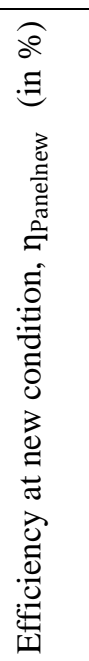 & 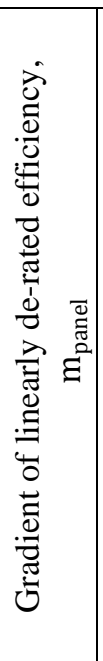 & 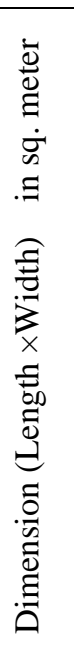 & 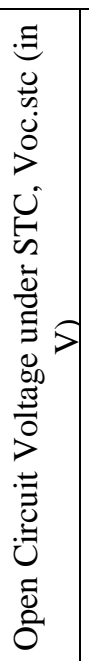 & 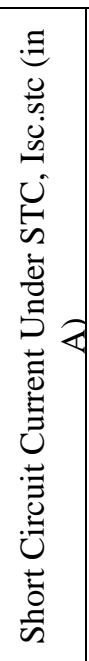 & 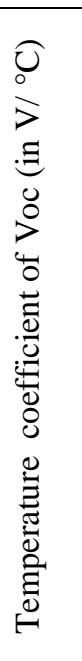 & 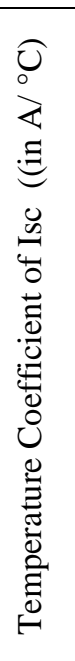 & 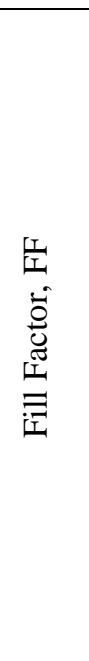 & 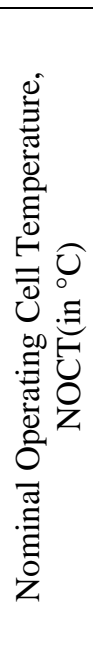 & 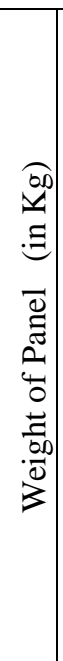 & 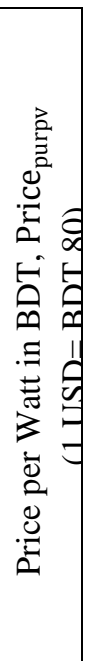 \\
\hline 1 & $\begin{array}{c}\text { Astronergy } \\
\text { VIOLIN } \\
\text { CHSM6610 } \\
\text { P-260 Silver } \\
\text { Poly Solar } \\
\text { Panel }\end{array}$ & $\begin{array}{l}\text { Astronerg } \\
\text { y Solar, } \\
\text { Germany }\end{array}$ & $\begin{array}{l}2 \\
6 \\
0\end{array}$ & $\begin{array}{l}2 \\
5\end{array}$ & $\begin{array}{c}15.9 \\
4\end{array}$ & -0.7 & $\begin{array}{c}1.6 \\
48 \times \\
0.9 \\
90\end{array}$ & \begin{tabular}{l|}
38. \\
53
\end{tabular} & $\begin{array}{c}8.7 \\
2\end{array}$ & $\begin{array}{c}- \\
0.11 \\
94\end{array}$ & $\begin{array}{c}+0 . \\
004 \\
27\end{array}$ & $\begin{array}{c}0.77 \\
4\end{array}$ & 45 & $\begin{array}{l}1 \\
8 . \\
4\end{array}$ & $\begin{array}{c}69 . \\
6\end{array}$ \\
\hline 2 & $\begin{array}{c}\text { Astronergy } \\
\text { ASM6612P } \\
-315 \text { Silver } \\
\text { Poly Solar } \\
\text { Panel }\end{array}$ & $\begin{array}{l}\text { Astronerg } \\
\text { y Solar, } \\
\text { Germany }\end{array}$ & $\begin{array}{l}3 \\
1 \\
5\end{array}$ & $\begin{array}{l}2 \\
5\end{array}$ & $\begin{array}{c}16.2 \\
0\end{array}$ & -0.7 & $\begin{array}{c}1.9 \\
56 \times \\
0.9 \\
94\end{array}$ & $\begin{array}{r}45 . \\
55\end{array}$ & $\begin{array}{c}9.0 \\
2\end{array}$ & $\begin{array}{c}- \\
0.14 \\
166\end{array}$ & $\begin{array}{c}+0 . \\
004 \\
51\end{array}$ & $\begin{array}{c}0.76 \\
6\end{array}$ & 48 & $\begin{array}{l}2 \\
3 . \\
5\end{array}$ & $\begin{array}{c}71 . \\
2\end{array}$ \\
\hline 3 & $\begin{array}{c}\text { SolarWorld } \\
\text { SW285 Plus } \\
\text { Black Mono } \\
\text { Solar Panel } \\
\end{array}$ & $\begin{array}{c}\text { Solar } \\
\text { World, } \\
\text { Germany }\end{array}$ & $\begin{array}{l}2 \\
8 \\
5\end{array}$ & $\begin{array}{l}2 \\
5\end{array}$ & 17.0 & -0.7 & $\begin{array}{c}1.6 \\
75 \times \\
1.0 \\
01 \\
\end{array}$ & $\begin{array}{c}39 . \\
7\end{array}$ & $\begin{array}{c}9.8 \\
4\end{array}$ & $\begin{array}{c}- \\
0.03 \\
05\end{array}$ & $\begin{array}{c}+0 . \\
004 \\
33\end{array}$ & $\begin{array}{c}0.72 \\
9\end{array}$ & 48 & $\begin{array}{l}1 \\
8 . \\
0\end{array}$ & $\begin{array}{c}85 . \\
6\end{array}$ \\
\hline 4 & $\begin{array}{c}\text { SolarWorld } \\
\text { SW320 XL } \\
\text { Silver Mono } \\
\text { Solar Panel }\end{array}$ & $\begin{array}{c}\text { Solar } \\
\text { World, } \\
\text { Germany }\end{array}$ & $\begin{array}{l}3 \\
2 \\
0\end{array}$ & $\begin{array}{l}2 \\
5\end{array}$ & $\begin{array}{c}16.0 \\
4\end{array}$ & -0.7 & $\begin{array}{c}1.9 \\
93 \times \\
1.0 \\
01 \\
\end{array}$ & $\begin{array}{c}45 . \\
9\end{array}$ & $\begin{array}{c}9.8 \\
1\end{array}$ & $\begin{array}{c}- \\
0.13 \\
95\end{array}$ & $\begin{array}{c}+0 . \\
004 \\
12\end{array}$ & $\begin{array}{c}0.74 \\
1\end{array}$ & 46 & $\begin{array}{l}2 \\
1 . \\
6\end{array}$ & $\begin{array}{l}75 . \\
20\end{array}$ \\
\hline 5 & $\begin{array}{c}\text { Suniva } \\
\text { OPT280- } \\
60-4-100 \\
\text { Silver Mono } \\
\text { Solar Panel }\end{array}$ & $\begin{array}{l}\text { Suniva, } \\
\text { America }\end{array}$ & $\begin{array}{l}2 \\
8 \\
0\end{array}$ & $\begin{array}{l}2 \\
5\end{array}$ & $\begin{array}{c}17.0 \\
4\end{array}$ & -0.7 & $\begin{array}{c}1.6 \\
60 \times \\
0.9 \\
90\end{array}$ & $\begin{array}{c}38 . \\
8\end{array}$ & $\begin{array}{c}9.5 \\
7\end{array}$ & $\begin{array}{c}- \\
0.12 \\
9\end{array}$ & $\begin{array}{c}+0 . \\
004 \\
97\end{array}$ & $\begin{array}{c}0.75 \\
4\end{array}$ & 46 & $\begin{array}{l}1 \\
7 . \\
9\end{array}$ & $\begin{array}{c}84 . \\
0\end{array}$ \\
\hline 6 & $\begin{array}{c}\text { Suniva } \\
\text { OPT285- } \\
60-4-100 \\
\text { Silver Mono } \\
\text { Solar Panel }\end{array}$ & $\begin{array}{l}\text { Suniva, } \\
\text { America }\end{array}$ & $\begin{array}{l}2 \\
8 \\
5\end{array}$ & $\begin{array}{l}2 \\
5\end{array}$ & $\begin{array}{c}17.3 \\
4\end{array}$ & -0.7 & $\begin{array}{c}1.6 \\
60 x \\
0.9 \\
90\end{array}$ & $\begin{array}{c}38 . \\
9\end{array}$ & $\begin{array}{c}9.7 \\
1\end{array}$ & $\begin{array}{c}- \\
0.12 \\
9\end{array}$ & $\begin{array}{c}+0 . \\
004 \\
97\end{array}$ & $\begin{array}{c}0.75 \\
4\end{array}$ & 46 & $\begin{array}{l}1 \\
7 . \\
9\end{array}$ & $\begin{array}{c}84 . \\
0\end{array}$ \\
\hline 7 & $\begin{array}{c}\text { Topoint } \\
\text { JTM190- } \\
\text { 72M Silver } \\
\text { Mono Solar } \\
\text { Panel }\end{array}$ & $\begin{array}{c}\text { Topoint, } \\
\text { China }\end{array}$ & $\begin{array}{l}1 \\
9 \\
0\end{array}$ & $\begin{array}{l}2 \\
5\end{array}$ & $\begin{array}{l}14.9 \\
\end{array}$ & 0.7 & $\begin{array}{c}1.5 \\
80 x \\
.80 \\
8\end{array}$ & $\begin{array}{c}43 . \\
8\end{array}$ & $\begin{array}{c}5.8 \\
3\end{array}$ & $\begin{array}{c}- \\
0.13 \\
9\end{array}$ & $\begin{array}{c}+0 . \\
001 \\
9\end{array}$ & $\begin{array}{l}0.74 \\
4\end{array}$ & 49 & $\begin{array}{l}1 \\
5 . \\
5\end{array}$ & $\begin{array}{l}67 . \\
20\end{array}$ \\
\hline 8 & $\begin{array}{c}\text { Panasonic } \\
325 \text { watt } \\
\text { Module } 96 \\
\text { Cell HIT - } \\
\text { Black Solar } \\
\text { Panel }\end{array}$ & $\begin{array}{c}\text { Panasonic } \\
\text {, Japan }\end{array}$ & $\begin{array}{l}3 \\
2 \\
5\end{array}$ & $\begin{array}{l}2 \\
5\end{array}$ & 19.4 & -1 & $\begin{array}{c}1.5 \\
90 \times \\
1.0 \\
53\end{array}$ & $\begin{array}{c}69 . \\
6\end{array}$ & $\begin{array}{c}6.0 \\
3\end{array}$ & $\begin{array}{c}- \\
0.17 \\
4\end{array}$ & $\begin{array}{c}+0 . \\
001 \\
82\end{array}$ & $\begin{array}{c}0.77 \\
4\end{array}$ & 49.2 & $\begin{array}{l}1 \\
8 . \\
5\end{array}$ & 112 \\
\hline
\end{tabular}


IJIREEICE

International Journal of Innovative Research in Electrical, Electronics, Instrumentation and Control Engineering

ISO 3297:2007 Certified

Vol. 5, Issue 2, February 2017

\begin{tabular}{|c|c|c|c|c|c|c|c|c|c|c|c|c|c|c|c|}
\hline 9 & $\begin{array}{l}\text { Hyundai } \\
\text { HiS- } \\
\text { M260RG } \\
\text { Black } \\
\text { Frame, } \\
\text { White } \\
\text { Backsheet } \\
\text { Poly Solar } \\
\text { Panel }\end{array}$ & $\begin{array}{c}\text { Hyundai, } \\
\text { South } \\
\text { Korea }\end{array}$ & $\begin{array}{l}2 \\
6 \\
0\end{array}$ & $\begin{array}{l}2 \\
5\end{array}$ & $\begin{array}{c}15.9 \\
4\end{array}$ & -0.8 & $\begin{array}{c}1.6 \\
4 \times 0 \\
.99 \\
8\end{array}$ & $\begin{array}{c}37 . \\
7\end{array}$ & 8.9 & $\begin{array}{c}- \\
0.12 \\
1\end{array}$ & $\begin{array}{c}+0 \\
004 \\
27\end{array}$ & $\begin{array}{c}0.77 \\
4\end{array}$ & 48 & $\begin{array}{l}1 \\
7 . \\
2\end{array}$ & 80 \\
\hline 10 & $\begin{array}{c}\text { LG } 320 \\
\text { NeON, } \\
\text { Mono, } \\
\text { Black } \\
\text { Frame - } \\
\text { LG320N1C } \\
\text {-G4 Solar } \\
\text { Panel }\end{array}$ & $\begin{array}{l}\text { LG, } \\
\text { Korea }\end{array}$ & $\begin{array}{l}3 \\
2 \\
0\end{array}$ & $\begin{array}{l}2 \\
5\end{array}$ & $\begin{array}{c}19.5 \\
0\end{array}$ & -0.7 & $\begin{array}{c}1.6 \\
4 \times 1 \\
.0\end{array}$ & $\begin{array}{c}40 . \\
9\end{array}$ & $\begin{array}{l}10 . \\
05\end{array}$ & $\begin{array}{c}- \\
0.11 \\
4\end{array}$ & $\begin{array}{c}+0 . \\
003 \\
01\end{array}$ & $\begin{array}{c}0.77 \\
8\end{array}$ & 49 & $\begin{array}{l}1 \\
7 . \\
5\end{array}$ & 115 \\
\hline 11 & $\begin{array}{c}\text { LG 315N1C } \\
\text { Black Mono } \\
\text { Solar Panel }\end{array}$ & $\begin{array}{l}\text { LG, } \\
\text { Korea }\end{array}$ & $\begin{array}{l}3 \\
1 \\
5\end{array}$ & $\begin{array}{l}2 \\
5\end{array}$ & $\begin{array}{c}19.2 \\
0\end{array}$ & -0.65 & $\begin{array}{r}1.6 \\
4 \times 1 \\
.00 \\
\end{array}$ & $\begin{array}{l}40 . \\
60\end{array}$ & $\begin{array}{l}10 . \\
02\end{array}$ & $\begin{array}{c}- \\
0.11 \\
36 \\
\end{array}$ & $\begin{array}{c}+0 . \\
003 \\
0 \\
\end{array}$ & $\begin{array}{c}0.77 \\
5\end{array}$ & 49 & $\begin{array}{l}1 \\
7 . \\
0\end{array}$ & $\begin{array}{c}112 \\
.5\end{array}$ \\
\hline 12 & $\begin{array}{c}\text { LG 310N1C } \\
\text { Black Mono } \\
\text { Solar Panel }\end{array}$ & $\begin{array}{l}\text { LG, } \\
\text { Korea }\end{array}$ & $\begin{array}{l}3 \\
1 \\
0\end{array}$ & $\begin{array}{l}2 \\
5\end{array}$ & $\begin{array}{c}18.9 \\
0\end{array}$ & -0.70 & $\begin{array}{r}1.6 \\
4 \times 1 \\
.00 \\
\end{array}$ & $\begin{array}{l}40 . \\
40\end{array}$ & $\begin{array}{c}9.9 \\
6\end{array}$ & $\begin{array}{c}- \\
0.11 \\
34 \\
\end{array}$ & $\begin{array}{c}+0 . \\
002 \\
98 \\
\end{array}$ & $\begin{array}{l}0.77 \\
0\end{array}$ & 49 & $\begin{array}{l}1 \\
7 . \\
0\end{array}$ & $\begin{array}{l}105 \\
.03\end{array}$ \\
\hline 13 & $\begin{array}{c}\text { LG 300N1K } \\
\text { Black on } \\
\text { Black Mono } \\
\text { Solar Panel }\end{array}$ & $\begin{array}{c}\text { LG, } \\
\text { Korea }\end{array}$ & $\begin{array}{l}3 \\
0 \\
0\end{array}$ & $\begin{array}{l}2 \\
5\end{array}$ & $\begin{array}{c}18.2 \\
9\end{array}$ & -0.70 & $\begin{array}{r}1.6 \\
4 \times 1 \\
.00\end{array}$ & $\begin{array}{l}39 . \\
70\end{array}$ & $\begin{array}{c}9.7 \\
0\end{array}$ & $\begin{array}{c}- \\
0.11 \\
11\end{array}$ & $\begin{array}{c}+0 . \\
002 \\
91\end{array}$ & $\begin{array}{l}0.77 \\
9\end{array}$ & 49 & $\begin{array}{l}1 \\
7 . \\
0\end{array}$ & $\begin{array}{l}106 \\
.40\end{array}$ \\
\hline 14 & $\begin{array}{c}\text { Solarland } \\
\text { SLP160S- } \\
12 \text { Silver } \\
\text { Mono Solar } \\
\text { Panel } \\
\end{array}$ & $\begin{array}{c}\text { Solarland } \\
\text {, China }\end{array}$ & $\begin{array}{l}1 \\
6 \\
0\end{array}$ & $\begin{array}{l}2 \\
5\end{array}$ & 15.8 & -0.70 & $\begin{array}{c}1.5 \\
0 \times 0 \\
.67 \\
5\end{array}$ & $\begin{array}{c}21 . \\
9\end{array}$ & $\begin{array}{c}9.6 \\
0\end{array}$ & -0.08 & $\begin{array}{c}+0 \\
006 \\
24\end{array}$ & $\begin{array}{c}0.76 \\
0\end{array}$ & 49 & $\begin{array}{l}1 \\
2 . \\
0\end{array}$ & $\begin{array}{c}162 \\
.4\end{array}$ \\
\hline 15 & $\begin{array}{c}\text { Solarland } \\
\text { SLP150-12 } \\
\text { Silver Poly } \\
\text { Solar Panel }\end{array}$ & $\begin{array}{l}\text { Solarland } \\
\text {, China }\end{array}$ & $\begin{array}{l}1 \\
5 \\
0\end{array}$ & $\begin{array}{l}2 \\
5\end{array}$ & 14.8 & -0.70 & $\begin{array}{c}1.5 \\
0 \times 0 \\
.67 \\
5\end{array}$ & $\begin{array}{c}22 . \\
2\end{array}$ & $\begin{array}{c}8.6 \\
8\end{array}$ & -0.08 & $\begin{array}{c}+0 . \\
005 \\
64\end{array}$ & $\begin{array}{l}0.77 \\
8\end{array}$ & 49 & $\begin{array}{l}1 \\
2 . \\
1\end{array}$ & $\begin{array}{l}173 \\
.38\end{array}$ \\
\hline
\end{tabular}

MCDA OPTIMIZATION FOR DIFFERENT WEIGHING OF CRITERIA

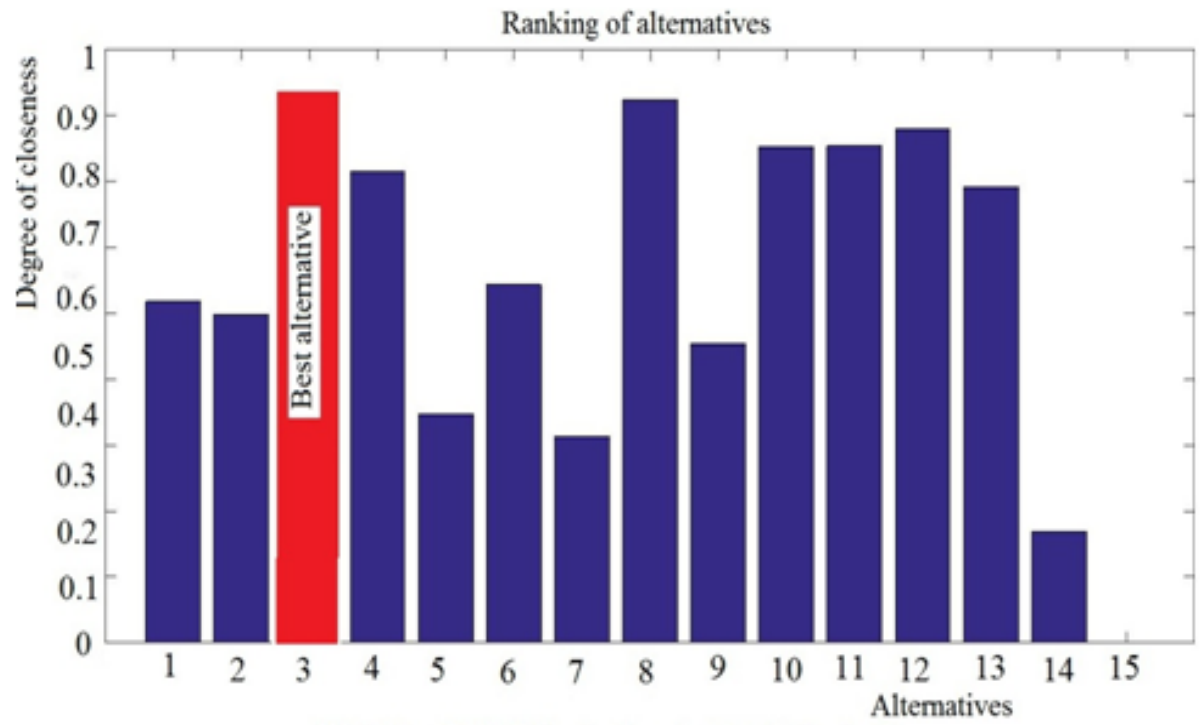

Weight : $25 \%$ Criteria- 1 and $75 \%$ Criteria- 2

Fig.I Ranking of alternative for $25 \%$ preference of criteria-1, and $75 \%$ preference of criteria-2 
International Journal of Innovative Research in Electrical, Electronics, Instrumentation and Control Engineering

ISO 3297:2007 Certified

Vol. 5, Issue 2, February 2017

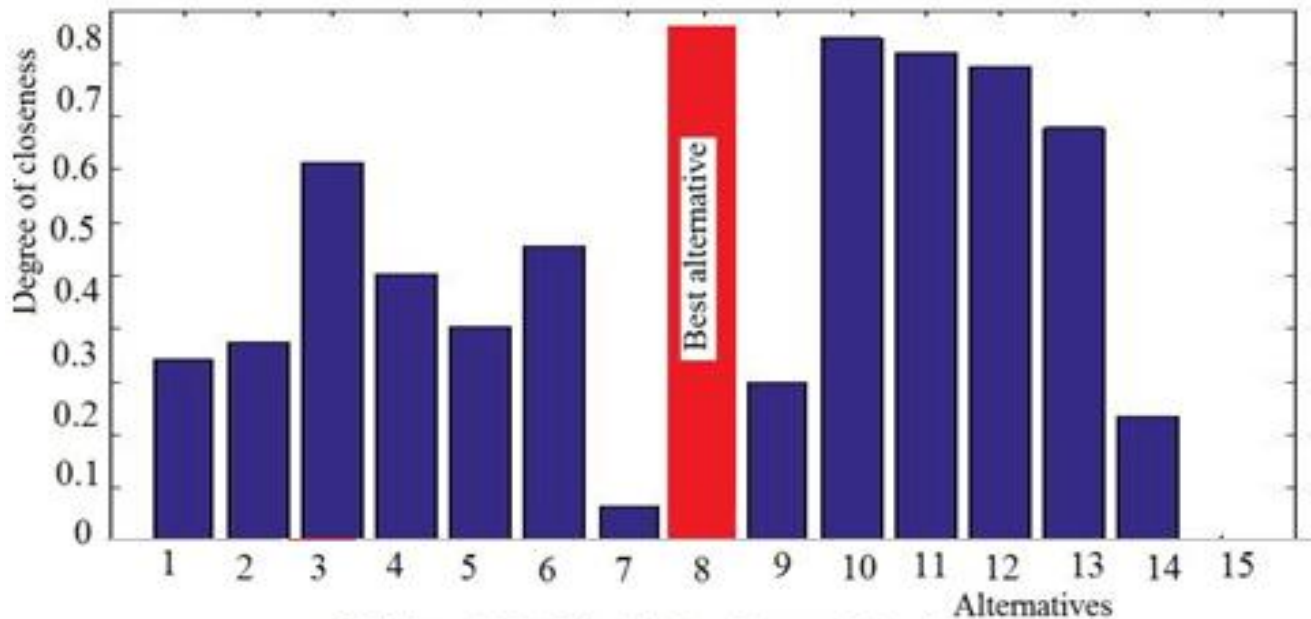

Weight : $75 \%$ Criteria- 1 and $25 \%$ Criteria- 2

Fig.II Ranking of alternative for $75 \%$ preference of criteria-1, and $25 \%$ preference of criteria-2

TABLE IV MCDA OPTIMIZED RESULT FOR DIFFERENT WEIGHING OF CRITERIA

\begin{tabular}{|c|c|c|c|c|c|}
\hline $\begin{array}{c}\text { Weighting of } \\
\text { Criteria-1 }\end{array}$ & $\begin{array}{c}\text { Weighting } \\
\text { of Criteria-1 }\end{array}$ & $\begin{array}{c}\text { Best } \\
\text { Alternative }\end{array}$ & Optimal Selection of Panel & $\begin{array}{c}\text { Requiremen } \\
\text { of area }\end{array}$ & $\begin{array}{c}\text { Per kWh } \\
\text { Cost }\end{array}$ \\
\hline $25 \%$ & $75 \%$ & 3 & SolarWorld SW285 Plus Black & 7.81 acres & $\begin{array}{c}\text { BDT } \\
\text { Mono Solar Panel }\end{array}$ \\
\hline $75 \%$ & $25 \%$ & 8 & $\begin{array}{c}\text { Panasonic 325 watt Module 96 } \\
\text { Cell HIT - Black Solar Panel }\end{array}$ & 7.15 acres & $\begin{array}{c}\text { BDT } \\
15.32\end{array}$ \\
\hline
\end{tabular}

